This is the pre-peer reviewed version of the following article: "Metamorphic zoning and behaviour of an underthrusting continental plate", which has been published in final form at DOI: $10.1111 / \mathrm{jmg} .12304$. This article may be used for noncommercial purposes in accordance with Wiley Terms and Conditions for Self-Archiving

\title{
Metamorphic zoning and behaviour of an underthrusting continental plate
}

\author{
Charlotte Möller ${ }^{1 *}$ and Jenny Andersson ${ }^{2}$ \\ ${ }^{1}$ Department of Geology, Lund University, Sölvegatan 12, SE-223 62 Lund, Sweden; \\ charlotte.moller@geol.lu.se \\ ${ }^{2}$ Geological Survey of Sweden, Box 670, SE-751 28 Uppsala, Sweden; \\ jenny.andersson@sgu.se
}

Short title: An exposed underthrusting continental plate

\begin{abstract}
Lower continental plates of collision zones are normally inaccessible and their properties inferred by geophysical surveying. By contrast, the eastern margin of the deeply eroded onebillion-year-old Sveconorwegian Orogen in Scandinavia exposes an underthrusting lower continental plate that records the metamorphic evolution and behaviour during collisional orogeny. A $200 \mathrm{~km}$ wide structurally coherent belt of the mid- to upper levels of the underthrusting lower plate, composed of Proterozoic igneous protoliths, exposes the gradual transition from unmetamorphosed to high-pressure granulite-facies. Metamorphic assemblages in Fe-Ti-rich metagabbro in a continuous $\sim 120 \mathrm{~km}$ wide transect across the lower continental plate define a regional metamorphic zoning by eight zones. Significant metamorphic recrystallization is first recorded at conditions of lower to middle amphibolitefacies $\left(550-600{ }^{\circ} \mathrm{C}\right)$, progressing successively towards the contact with the upper plate to high-pressure granulite-facies at $\sim 850{ }^{\circ} \mathrm{C}$ and $10-11 \mathrm{kbar}$, the latter corresponding to $\sim 40 \mathrm{~km}$ depth. An eclogite-bearing tectonic terrane, detached from the leading edge of the underthrusting plate and extruded back along the interface with the overlying crust, occurs just beneath the lithotectonic contact of the overriding plate. The gradual metamorphic transition demonstrates that, with the exception of the eclogite-bearing terrane, the underthrusting plate remained essentially structurally coherent despite highly ductile deformation and partial melting. The metamorphic rocks record that, by and large, the underthrusting plate underwent short-lived metamorphic recrystallization and deformation that started first at an advanced stage of collision, at c. 980-970 Ma; this is in contrast to the eclogite-bearing terrane which records more protracted metamorphic recrystallization both through prograde metamorphism and decompression. The investigated section is the first described in situ exposure of a coherent underthrusting lower continental plate, and defines a metamorphic field gradient at higher temperatures and P/T than the classical Barrovian style. The exposed section provides potential for increasing understanding of the thermal evolution, rheology, petrophysical properties, and distribution of volatiles in an elsewhere inaccessible part of Earth's collisional systems. The data demonstrate that the underthrusting lower continental plate differs in metamorphic character from other parts of orogenic systems in that the crust is relatively dry, competent, and responds by significant metamorphic recrystallization first at elevated temperatures (middle amphibolite-facies) and that metamorphic recrystallization is largely coupled to deformation that facilitates the entry of hydrous fluids into the crust.
\end{abstract}

Key words: collision, Sveconorwegian, partial melting, eclogite, granulite, metagabbro

This article has been accepted for publication and undergone full peer review but has not been through the copyediting, typesetting, pagination and proofreading process, which may lead to differences between this version and the Version of Record. Please cite this article as doi: 10.1111/jmg. 12304

This article is protected by copyright. All rights reserved. 


\section{1 | INTRODUCTION}

"The rocks of the Indian subcontinent are last seen south of the Ganges before they plunge beneath the Himalaya and the Tibetan plateau."

(Schulte-Pelkum et al., 2005)

The introductory sentence of Schulte-Pelkum et al. (2005) illustrates that in young orogens the thermal state and rheology of middle and deep crust, in this case the Indian plate beneath Himalaya and Tibet, must be assessed by indirect methods, i.e. geophysical surveying. The properties of the Indian lower crust are topics of long-standing discussion (Copley, Avouac, \& Wernicke, 2011), because the deep crust controls mechanical behaviour and affects the dynamic evolution of entire orogens (e.g., Jamieson, Unsworth, Harris, Rosenberg, \& Schulmann, 2011). Seismic low-velocity regions under the Tibetan plateau have been interpreted as melt-weakened crust capable of highly ductile flow (Nelson et al., 1996; Unsworth et al., 2005), and melt-enhanced exhumation of mid-crustal rocks appears to be corroborated by the presence of leucogranite and migmatite in the Greater Himalayan Sequence (Searle, Cottle, Streule, \& Waters, 2010). In contrast, the underthrusting Indian lower plate is interpreted as rigid, supporting the elevation of Tibet (Jackson, Austrheim, McKenzie, \& Priestley, 2004; Jackson, McKenzie, Priestley, \& Emmerson, 2008; Nábělek et al., 2009). Geophysical data indicate that the Indian lower plate beneath the Himalayan prism and southern Tibet is essentially intact (Zhao, Nelson, \& Project INDEPTH Team, 1993).

The metamorphic state of the Indian lower plate has been alternately interpreted as granulite(dry), amphibolite- (wet), or eclogite-facies (very high-density; Craig, Copley, \& Jackson, 2012; Hetényi et al., 2007; Schulte-Pelkum et al., 2005).

While young orogens expose thick orogenic prisms and far-travelled nappes, deeply eroded Precambrian shields offer access to the innermost, deep-seated levels of orogens. The Sveconorwegian Orogen in the Baltic Shield (Scandinavia) is an example of a collisional orogen formed during the $1 \mathrm{Ga}$ assembly of the supercontinent Rodinia (Figure 1; Bingen, Andersson, Söderlund, \& Möller, 2008a; Li et al., 2008; Möller, Andersson, Dyck, \& Lundin, 2015). The remnants of this orogen are present in a $500 \mathrm{~km}$ wide belt, in which upper crustal thin-skinned nappes have been excised and eroded, leaving mid- and deep crustal levels exposed. The Sveconorwegian orogenic evolution was coeval with that of the Grenville Orogen, and shares similar first-order architecture (Möller et al., 2015; Rivers, 2008).

In collisional orogens, the upper parts of the lower continental plate may become detached, thrust, and inserted into the orogenic prism. For example in the $0.5-0.4 \mathrm{Ga}$ Scandinavian Caledonides, Proterozoic 'basement' occurs both in windows at low tectonostratigraphic levels and in the allochthonous pile (Gee, Kumpulainen, Roberts, Stephens, \& Zachrisson, 1985). The Western Gneiss Region (WGR), the largest basement window in the hinterland and famous for its eclogite occurrences, is dominated by Proterozoic rocks that were deeply buried during Caledonian collision. Large parts of the WGR are, however, not coherent with the underthrusting lower continental plate. The internal structure of the WGR is complex with tectonic repetition and tight folding of intercalated basement and cover units (cf. maps compiled by Arne Solli, Geological Survey of Norway, published as Figures 1 and 4 in Krogh, Kamo, Terry, Robinson, \& Kwok, 2011; Robinson, Roberts, Gee \& Solli, 2013). Similarly in the Grenville Orogen, the structurally lowest units that are exposed along the front zone form an imbricate thrust stack composed of a Palaeoproterozoic continental margin sequence and meta-igneous rocks (e.g., Bethune \& 
Davidson, 1997; Brown, van Gool, Calon, \& Rivers, 1991; Indares, 1995; Indares \& Rivers, 1995; Rivers et al., 2012).

This paper reports on the metamorphic zoning and properties across the underthrusting continental plate of the Sveconorwegian Orogen: the Eastern Segment (Figure 1c). In contrast to basement that has been detached from the underthrusting plate and incorporated into the orogenic prism, the Eastern Segment represents an exposure of the underthrusting plate itself. The Eastern Segment and its continuation in unmetamorphosed parts of the Baltic Shield form a $200 \mathrm{~km}$ transition, from a state essentially unaffected by Sveconorwegian metamorphism and deformation to high-grade metamorphism and ductile structures on approaching the deep-seated boundary of the overlying plate. The formerly deeply buried crust consists of high-grade gneisses with high-pressure granulite (9-11 kbar, corresponding to $\sim 35-45 \mathrm{~km}$ ) and an eclogite-bearing terrane ( $\sim 18 \mathrm{kbar}$, corresponding to $\sim 65 \mathrm{~km}$ depth), demonstrating doubly thickened continental crust comparable to the Himalayas. The metamorphic field gradient, the deformation state, and the distribution of migmatite and eclogite provide key reference data for interpretation of the rheology and behaviour of lower continental plates at orogenic depths which normally are inaccessible.

While the metamorphic characteristics of orogenic prisms in subduction zonearc and continent collisional systems are known across the Earth (Johnson \& Harley, 2012), this paper presents, to our knowledge, the first documentation of large-scale coherent in situ metamorphic zoning in a lower continental plate involved in continent-continent collision. The metamorphic record of the Eastern Segment demonstrates that lower continental plates behave as a distinctly different metamorphic system to water-saturated systems.

\section{2 | REGIONAL CONTEXT}

\subsection{The Sveconorwegian Orogen}

The Sveconorwegian Orogen is the tectonic counterpart to the Grenville Orogen and formed during assembly of the supercontinent Rodinia (Figure 1a; Li et al., 2008). The tectonic setting has been interpreted as either collisional (Bingen, Nordgulen, \& Viola, 2008b; Möller et al., 2015, Figure 1b) or accretionary (Coint et al., 2015), involving east-dipping or westdipping subduction beneath the western Sveconorwegian terranes. The orogen comprises five lithotectonic segments or terranes bound by ductile shear zones: the Eastern Segment and the Idefjorden, Kongsberg, Bamble, and Telemarkia terranes (Figure 1c; Bingen et al., 2008a). The oldest metamorphic event is recorded in the Bamble and Kongsberg terranes, as highpressure granulite- and amphibolite-facies metamorphism and deformation at $c .1 .14 \mathrm{Ga}$ (Engvik et al., 2016). The Bamble and Kongsberg terranes probably resided at upper crustal levels during subsequent orogenesis since they remained unaffected by later metamorphism (Bingen et al., 2008b). In the Telemarkia and Idefjorden terranes, situated on either side of Bamble and Kongsberg, metamorphism and migmatization took place at 1.05-1.00 Ga (Bingen et al., 2008b; Laurent et al., 2016). Eastern parts of the Idefjorden terrane record high-pressure amphibolite- and high-pressure granulite-facies metamorphism at 1.05-1.02 Ga (Bingen et al., 2008b; Söderlund, Hellström, \& Kamo, 2008a). This metamorphism was approximately coeval with 1.07-1.02 Ga granite magmatism in Telemarkia (Coint et al., 2015).

Younger metamorphism, deformation, and migmatization in the Idefjorden terrane, dated at $c .0 .98 \mathrm{Ga}$, have been identified along its tectonic contact with the Eastern Segment, known as the Mylonite Zone (MZ in Figure 1c; Andersson, Möller, \& Johansson, 2002). An eclogite-bearing terrane in the Eastern Segment, situated in the immediate footwall of the MZ, has yielded an age of $0.99 \mathrm{Ga}$ for the eclogite metamorphism (Möller et al., 2015; 
Tual, Pitra, \& Möller, 2017), thereby linking its metamorphic evolution to that of the Eastern Segment. It is thus interpreted to have been derived from the leading edge of the subducted Eastern Segment following crustal doubling, and to have been thrust back over it as a large lower-crustal nappe (op. cit.). The eclogite-facies metamorphism and crustal doubling recorded in the Eastern Segment has been interpreted as either an 'India-style' continental collision, or alternatively as due to intracontinental thickening related to collision (Möller et al., 2015). In either case, it testifies to the Eastern Segment underthrusting the western Sveconorwegian terranes. Partial exhumation of the eclogite-bearing terrane at 0.98-0.97 Ga was coeval with high-pressure granulite- and upper amphibolite-facies metamorphism, ductile deformation, and migmatization of the internal section of the Eastern Segment (Möller, Andersson, Lundqvist, \& Hellström, 2007; Möller et al., 2015). Following crustal doubling, extension commenced at $0.97-0.96 \mathrm{Ga}$ across the orogen, lasting until at least 0.92 $\mathrm{Ga}$. In the Eastern Segment and its unmetamorphosed continuation eastward in the Baltic Shield, this extension is manifested by $0.97-0.94$ Ga orogen-parallel pegmatite and dolerite intrusions (Söderlund et al., 2005; Möller et al., 2007). In the western Sveconorwegian terranes, emplacement of ferroan granites initiated at $0.99 \mathrm{Ga}$, and culminated at $0.95-0.92$ $\mathrm{Ga}$, coeval with intrusion of $0.95-0.93 \mathrm{Ga}$ dolerite dykes and $0.93-0.92 \mathrm{Ga}$ post-orogenic plutons of granite, norite, and anorthosite (see compilation by Bingen et al., 2008b; Brueckner, 2009).

\section{2 | The Eastern Segment}

\subsection{1 | The pre-Sveconorwegian continent Baltica}

The Eastern Segment is mainly composed of rocks of the 1.86-1.66 Ga Transscandinavian Igneous Belt (Figure 1c). This magmatic belt formed in an Andean-type orogen and is composed of granite (dominantly), granodiorite to quartz-monzonite and quartzmonzodiorite, and subordinate mafic rocks and meta-volcanic slivers (Nolte, Kleinhanns, Baero, \& Hansen, 2011; Petersson, Scherstén, Andersson, \& Möller, 2013; Stephens \& Andersson, 2015). Mesoproterozoic intrusions are subordinate and include 1.57-1.56 Ga gabbro, and 1.47-1.38 Ga and 1.24-1.18 Ga granite, monzonite, gabbro and anorthosite (Brander \& Söderlund, 2009; Söderlund et al., 2005, Söderlund \& Ask, 2006). The southernmost Baltic Shield, including the southern Eastern Segment, also records lowpressure metamorphism, partial melting, and leucogranitic dyke intrusion at 1.47-1.38 Ga (Brander, Appelqvist, Cornell, \& Andersson, 2012; Söderlund, Möller, Andersson, Johansson, \& Whitehouse, 2002; Ulmius, Andersson, \& Möller, 2015).

\subsubsection{Sveconorwegian metamorphism and deformation}

At the present erosion level, the eastern boundary of Sveconorwegian ductile deformation is located along the steeply west-dipping Sveconorwegian Front [Figure 1c; Sveconorwegian Frontal Deformation Zone of Wahlgren, Cruden, and Stephens (1994)]. At the time of the Sveconorwegian orogeny, however, upper crustal nappes and sediments covered the continent $>200 \mathrm{~km}$ farther east, as evidenced by sub-greenschist facies deformation structures in remnants of sedimentary rocks (Rodhe, 1987) and fracture fillings in Proterozoic igneous rocks (Drake, Tullborg, \& Page, 2009; Saintot, Stephens, Viola, \& Nordgulen, 2011). The Sveconorwegian Front marks the eastern limit of discrete east-vergent, thrust-sense, ductile deformation in the Proterozoic bedrock (Wahlgren et al., 1994). These sparse and narrow deformation zones developed within the upper- to mid-crustal basement at an unknown depth, likely within 10-25 km, where the bedrock responded by non-penetrative greenschistfacies shear. The corridor immediately west of the Sveconorwegian Front, the frontal wedge (Figure 1c), is a fan-shaped, vertical to steeply west-dipping deformation zone, with westside-up and top-to-the-east kinematics and amphibolite-facies parageneses (Andréasson \& 
Rodhe, 1990; Wahlgren et al., 1994); deformation and metamorphic recrystallization was non-penetrative. Younger brittle-ductile and brittle faults are also localized in this zone.

In the transitional section (Figure 1c), west of the frontal wedge, structures change over a few kilometres from subvertical shear zones to upright, inclined, or recumbently folded foliations, about gently east-dipping fold axes (Möller et al., 2015). Here, rocks are penetratively ductilely deformed and metamorphosed under intermediate amphibolite-facies conditions. Farther west, the boundary with the internal section (Figure 1c) is defined by the appearance of granitic leucosome in felsic rocks; this boundary is transitional over a distance of a kilometre. To the west, within the internal section, the rocks are metamorphosed to high grade and generally penetratively deformed, with leucosome in both felsic and mafic rocks. High-pressure granulite-facies rocks occur in the westernmost part of the internal section (Johansson, Lindh, \& Möller, 1991; Wang \& Lindh, 1996).

An eclogite-bearing nappe occurs at the contact with the Idefjorden Terrane (Figure1c; Möller et al., 2015). Eclogite and retrogressed eclogite, with country rock migmatitic orthogneiss derived from the Eastern Segment, are contained within a major recumbent fold. Eclogite metamorphism took place at $\sim 870 \mathrm{C}$ and $18 \mathrm{kbar}$, corresponding to a depth of $\sim 65 \mathrm{~km}$ (Tual et al., 2017). The eclogite-bearing nappe was tectonically emplaced into its present position at $\sim 10 \mathrm{kbar}(35-40 \mathrm{~km}$ depth) during partial exhumation, caused by foreland-directed extrusion, and is structurally concordant with surrounding rocks (Möller et al., 2015; Tual, Pinan-Llamas, \& Möller, 2015). Its contact is outlined by an augen gneiss unit in the footwall, and the base of the eclogite-bearing nappe is a thrust zone of hightemperature mylonitic rocks. The rocks in the eclogite-bearing nappe underwent syntectonic migmatization during exhumation, and the eclogites record partial re-equilibration under high-pressure granulite- and upper amphibolite-facies conditions.

The eclogite-bearing nappe occurs structurally beneath the contact of the overlying Idefjorden terrane and the crustal-scale Mylonite Zone (MZ, Figure 1c; Stephens, Wahlgren, Weijermars, \& Cruden, 1996). The Mylonite Zone marks the main lithotectonic contact between the Eastern Segment and the western Sveconorwegian terranes, in the southern part with late Sveconorwegian high-grade gneissic structures on either side, in the Idefjorden terrane above and the Eastern Segment below (Andersson et al., 2002).

\subsection{3 | Timing of metamorphism}

$\mathrm{U}-\mathrm{Pb}$ ages of metamorphic zircon in metabasic rocks and felsic gneisses, including migmatitic varieties, date metamorphism in the Eastern Segment between 1.00 and $0.96 \mathrm{Ga}$ (Figure 2; Table 1 including references). $\mathrm{U}-\mathrm{Pb}$ zircon dates older than $0.98 \mathrm{Ga}$ are (so far) restricted to prograde and eclogite-facies zircon in eclogite. Metamorphic zircon in metagabbro in other parts of the Eastern Segment has yielded ages of $970 \pm 7 \mathrm{Ma}$ (breakdown of baddeleyite) and $974 \pm 25 \mathrm{Ma}$. Well-constrained ages of zircon crystallization in leucosome of both mafic and felsic migmatites fall between $976 \pm 7$ and $968 \pm 13 \mathrm{Ma}(\mathrm{n}=7)$.

Post-kinematic cross-cutting granite-pegmatite dykes have yielded ages between $956 \pm 7$ and $934 \pm 6 \mathrm{Ma}(\mathrm{n}=7) .{ }^{40} \mathrm{Ar}-{ }^{39} \mathrm{Ar}$ cooling ages of hornblende and muscovite are between c. 940 and 900 Ma (Page, Möller, \& Johansson, 1996).

\section{3 | METHODS}

Data have been retrieved from field investigation and petrographic documentation of thousands of locations in the Eastern Segment, and a selection of 276 locations and samples of Fe-Ti-rich metagabbro was used for the definition of metamorphic zones. Zones 1-6 are 
based on petrographic microscopy, and zones 7 and 8 on macroscopic and microscopic identification of megablastic minerals in leucosome. Field observations and samples were retrieved during the course of 30 years, beginning in 1988 with metamorphic and geochronological studies, later coupled with bedrock mapping from 2003 to 2016 at scales of 1:250 000 and 1:50 000 by the Geological Survey of Sweden (SGU), and, beginning in 2010, research-targeted mapping (scale 1:10 000) by the Department of Geology at Lund University. The geographical distribution of bedrock maps and observations points available from SGU are shown in Figure S1.

\section{4 | REGIONAL METAMORPHIC ZONING}

The metamorphic characteristics of the investigated area in the Eastern Segment are presented below; assemblages of the different zones are summarized in Table 2, and the metamorphic map presented in Figure 3. An overview map of the geographic distribution of the investigated metagabbro samples is shown in Figure S2. Geographic coordinates for Figures 4-8 are given in Table S1.

\section{1 | Definition of metamorphic zones}

Eight metamorphic zones in the Eastern Segment are defined on the basis of metamorphic assemblages in Fe-Ti-rich metagabbro, a widespread protolith with three or four emplacement ages between 1.6 and 1.0 Ga. Changes in metamorphic assemblages in zones 16 are tracked in metagabbro devoid of leucosome. In zone 6 and higher (westernmost areas), the assemblage in non-migmatized metagabbro does not change. Instead, changes in zones 7 and 8 are monitored by different peritectic minerals in leucosomes in Fe-Ti-rich migmatitic garnet amphibolite. Most metagabbro samples contain small amounts of quartz. Metagabbro with minute spinel grains in plagioclase appears to have stabilized orthopyroxene in lower grade zones than quartz-bearing metagabbro; one such sample was therefore excluded from the data set. Similarly, orthopyroxene occurring exclusively within pseudomorphs after olivine was discounted (i.e., lack of chemical equilibration on the thin section scale).

\subsection{Metamorphic zones 1 and 2: blue-green hornblende \pm garnet, in the frontal wedge}

East of zone 1, in the eastern frontal wedge, sparse and narrow greenschist-facies deformation zones occur, but most of the bedrock has remained in a pristine igneous or preSveconorwegian metamorphic state (Figures 1c and 3; Wahlgren et al., 1994; Ulmius et al., submitted).

Zone 1 is characterized by abundant N-S striking and steeply dipping anastomosing amphibolite-facies deformation zones of variable width, in most places less than a few decimetres wide (Figure 4a). This deformation affects 1.9-1.7 Ga rocks of the Transscandinavian Igenous Belt, intercalated metavolcanic slivers, and younger 1.6-1.2 Ga intrusions of gabbro and syenitoids. Complete metamorphic recrystallization is restricted to the deformation zones, which become more closely spaced towards the west and transect all rock types. Where deformed, Fe-Ti-rich metagabbro consists of blue-green hornblende, plagioclase, Fe-Ti-oxide, and biotite, locally with titanite and/or epidote. The anastomosing texture of the deformed rocks, with lens-shaped aggregates of plagioclase and dark minerals, respectively, show that the igneous protoliths were originally medium- to coarse-grained (Figure 4b,c). Undeformed gabbroic rocks retain primary igneous texture and minerals (pyroxene and plagioclase), but near deformation zones they have either developed coronas rich in blue-green amphibole around igneous pyroxene, or more or less complete pseudomorphs after pyroxene. 
The presence of garnet in metagabbro defines zone 2. The first appearance of garnet in metagabbro is located close to the western border of the frontal wedge (Figure 3 ). The metamorphic minerals, other than garnet, and deformation structures in zone 2 are similar to those in zone 1 (Figure $4 \mathrm{~d}$ ).

\subsection{Metamorphic zone 3: green hornblende+garnet, in the transitional section}

In the transitional section (Figures 1c and 3), rocks were metamorphosed under intermediate amphibolite-facies conditions. In the metagranitic rocks, deformation fabrics are gneissose with complete metamorphic recrystallization of major minerals (Figure 5a,b), but the rocks lack signs of partial melting. Competent rocks, e.g. gabbro, locally preserve igneous assemblages and are variably transected by amphibolite facies shear zones (Figure 5c-e; Beckman, Möller, Söderlund, \& Andersson, 2017). The characteristic assemblage in deformed and recrystallized Fe-Ti-rich gabbro is green hornblende, plagioclase, garnet, biotite, Fe-Ti-oxide, and locally epidote and/or titanite (Figure 5d-f); garnet locally reaches 6-7 mm in diameter. Coronitic texture is abundant in undeformed or weakly deformed metagabbro. Garnet is typically located at the border of plagioclase domains in these coronitic rocks. In some of the coronitic metagabbros, amphibole in coronas around igneous pyroxene is blue-green in colour.

\section{4 | Metamorphic zones 4-6: garnet with olive-green hornblende, clinopyroxene, and orthopyroxene, in the internal section}

The internal section, beginning $~ 50 \mathrm{~km}$ west of the Sveconorwegian Front (Figures 1c and 3), is characterized by the presence of leucosome in both granitic and gabbroic compositions (Figure $6 \mathrm{a}-\mathrm{c}$ ). Non-migmatitic felsic and mafic rocks are also present. Leucosome is associated with a range of deformation structures, including stromatic veins, which are locally folded, dilational veins, net texture veins, and veins parallel to the axial planes of small-scale folds, as well as small leucosome patches. Gradual transitions between nonmigmatitic and migmatitic varieties are present in some large mafic bodies, whereas other bodies are either non-migmatitic or penetratively migmatized.

The leucosome-free metagabbroic rocks occur as undeformed (Figure 6d) to weakly or moderately deformed bodies (foliated and/or lineated; Figure 6e). They range from fine- and even-grained to relict coarse-grained and coronitic-textured rocks with remnants of coarse igneous clinopyroxene (Figures 6e,f). The relict igneous pyroxene is characteristically "dusted" by minute Fe-Ti oxide grains (Figure 6e).

In zone 4, the metamorphic assemblage in non-migmatitic metagabbro consists of olive-green hornblende, plagioclase, garnet, biotite, and Fe-Ti-oxide, generally without epidote and titanite. In zone 5, 10 km farther west, the assemblage is the same as in zone 4, but in addition contains metamorphic clinopyroxene, typically as small, clear, light green, sub-granoblastic neoblasts, and as clear rims on the relict igneous clinopyroxene grains. In zone $6, \sim 20-30 \mathrm{~km}$ farther west, orthopyroxene and commonly antiperthite join the assemblage. Plagioclase in most rocks is completely recrystallized to granoblastic aggregates even in undeformed and originally coarse-grained metagabbro; remnants of primary laths are rare. Locally, rutile is present in subordinate amounts in metagabbro in zones 4-6.

The metamorphic assemblages of migmatitic amphibolite appear similar throughout zones 4 to 6 . Migmatitic amphibolite is dominated by olive-green hornblende, plagioclase, garnet, biotite, Fe-Ti-oxide and plagioclase-quartz leucosome; locally clinopyroxene occurs. Most migmatitic amphibolites are rich in garnet. Garnet occurs in 
leucosome at the first appearance of leucosome (Figure 6c; olive-green hornblende zone 4). The maximum size of garnet increases from $\sim 0.5 \mathrm{~cm}$ in the olive-green hornblende zone to 2 $\mathrm{cm}$ in the orthopyroxene zone. With the (possible) exception of garnet, leucosome is devoid of peritectic minerals and is tonalitic in composition, consisting of plagioclase and quartz. Retrograde minerals are more common in migmatitic amphibolite than in non-migmatitic metagabbro, and include titanite, formed at the expense of Fe-Ti oxide, and epidote.

\section{5 | Metamorphic zones 7-8: peritectic orthopyroxene and megablastic garnet in the internal section}

In zones 7 and 8 (Figure 3), non-migmatitic metagabbro consists of the same assemblage as in zone 6 . There is, however, a geographically systematic difference in the distribution of peritectic phases in leucosome in migmatitic garnet amphibolite. Megablastic $0.5-6 \mathrm{~cm}$ orthopyroxene in leucosome (Figure 7a) appears $\sim 90 \mathrm{~km}$ west of the Sveconorwegian Front, and is common in zones 7 and 8 (Figure 3; Hansen et al., 2015). This megablastic orthopyroxene has a characteristic corona of fine-grained garnet, clinopyroxene, and hornblende (Figure 7a), that likely developed during cooling.

In the westernmost areas (zone $8, \sim 110 \mathrm{~km}$ from the Sveconorwegian Front) megablastic garnet (Figure $7 \mathrm{~b}$ ) reaches $4 \mathrm{~cm}$ or more. Locally giant garnet megablasts are 20 $\mathrm{cm}$ in diameter. Rare peritectic clinopyroxene occurs in zone 8. It occurs in leucosome in garnet amphibolite, but also locally in migmatitic felsic gneiss, and forms poikiloblasts, up to $3 \mathrm{~cm}$ long and almost skeletal, rich in composite plagioclase + quartz inclusions (inferred tonalitic melt; Figure 7c). This texture can potentially be mistaken for decompressed omphacite, but the textural association with leucosome demonstrates that these clinopyroxene grains have grown in melt.

Despite high metamorphic temperature in zones $7-8$, non-migmatitic metagabbro in many places retains textural remnants of igneous clinopyroxene. Originally coarse-grained metagabbro has thick garnet coronas (Figure 7d). As a rule, fine-grained metagabbro has a strong deformation fabric defined by high-grade mineral aggregates.

Whereas felsic orthogneisses in zones 1-6 are typically hornblende- and biotitebearing, in zones $7-8$ they are also pyroxene-bearing. In $\sim 40 \%$ of the investigated thin sections of felsic orthogneiss in zones 7 and 8, two-pyroxene- and garnet-bearing metamorphic parageneses are present in both $1.7 \mathrm{Ga}$ and $1.4 \mathrm{Ga}$ orthogneiss (the latter being the Varberg charnockite). These 'dry' metamorphic assemblages typically define a Sveconorwegian regional, strongly gneissic, deformation fabric (Figure 7e,f). Remnant igneous orthoclase occurs in both generations of orthogneiss; igneous orthoclase grains locally occur as porphyroclasts wrapped by thin trails of recrystallized metamorphic feldspar and coarse ribbon- and lens-shaped quartz aggregates. Metamorphic feldspar in the 'dry' gneisses is grey microperthite, antiperthite, and locally mesoperthite.

\subsection{Recrystallization trend across zones $1-8$}

Pristine igneous rocks are found only in zones 1 and 2. In zone 3, even the best preserved, undeformed and coarse-grained gabbro has thin metamorphic coronas around the igneous minerals (Beckman et al., 2017). The metamorphic temperature increase across zones $1-8$ is accompanied by an increasing degree of recrystallization of igneous plagioclase and pyroxene. As a rule, igneous plagioclase in undeformed metagabbro is well-preserved in the frontal wedge, (zones 1-2) partly preserved in the transitional section (zone 3), and completely recrystallized in the highest-grade zones 6-8. Likewise, igneous pyroxene is 
better preserved in lower grade zones. Textural remnants of igneous clinopyroxene, characteristically 'dusted' by tiny, presumably exsolved, opaque inclusions, occur throughout the section; these oxide inclusions in relict igneous clinopyroxene typically become coarser in the highest grade zones.

\section{7 | The eclogite-bearing terrane}

The setting, petrology and geochronology of the eclogite-bearing terrane have been described in detail by Möller (1998, 1999), Johansson et al. (2001), Möller et al. (2015), and Tual et al., $(2015,2017)$. A brief description is given below.

Eclogite and retrogressed eclogite occur as layers and lenses in orthogneiss. In most parts of the eclogite-bearing domain, orthogneisses are stromatic migmatite (Figure 8a). The southernmost part of the domain is a north-dipping basal shear zone, up to $4 \mathrm{~km}$ wide, with high-temperature mylonitic gneiss and retro-eclogite boudins (Figure 8b). Migmatization and deformation took place during east-vergent partial exhumation of the eclogitized terrane. The terrane occurs as a recumbently folded nappe, refolded by younger upright folds, its structure outlined by deformed $1.4 \mathrm{Ga}$ augen orthogneiss in the footwall. The mylonitic assemblages are high-pressure granulite- and upper amphibolite-facies, similar to the assemblages in the enclosing gneisses outside the eclogite domain. The largest eclogite is a $2 \times 1.5 \mathrm{~km}$ sized layered mafic body in the basal shear zone. Two types of comparably well-preserved eclogite are present: kyanite-bearing Mg-Al-rich, and Fe-Ti-rich, eclogite (Figure 8c). Textures and assemblages in these rocks demonstrate that they were plagioclasefree, and growth zoning in garnet records a prograde evolution peaking at $\sim 870{ }^{\circ} \mathrm{C}$ and 18 kbar (Figure 8d), after which the rocks underwent near-isothermal decompression under highto intermediate-pressure granulite-facies conditions. Further retrogression under lower amphibolite-facies conditions is abundant in the pervasively migmatitic parts of the nappe.

\section{5 | INTERPRETATION AND DISCUSSION}

\section{1 | The exposed underthrusting continental plate}

\subsubsection{The metamorphic field gradient}

The systematic change in metamorphic assemblage of Fe-Ti-rich metagabbro along a $120 \mathrm{~km}$ section across the Eastern Segment provides qualitative evidence for a gradually increasing temperature from east to west, from low-middle amphibolite-facies in zones 1 and 2 to highpressure granulite-facies conditions in zones 5-8. This pattern suggests an overall structural coherence across zones $1-8$, without major tectonic breaks. An exception to this coherence is in southern areas, where the metamorphic data suggest that zones 2-4 are missing (Figure 3). This may be explained by late- and post-metamorphic faulting along the frontal wedge, with uplift of the western block.

Quantification of the metamorphic conditions across zones 1-8 requires systematic estimates, using an internally consistent thermodynamic data set or another method suitable for the range in temperature; this has not yet been performed. Nevertheless, the previously estimated pressure range of 9-11 kbar for zones 5-8 appears consistent with the metamorphic assemblages. Early $P-T$ estimates based on geothermobarometry of mafic granulite and decompressed eclogite are $680-770{ }^{\circ} \mathrm{C}$ and 8-11 kbar (Johansson et al., 1991; Möller, 1998; Wang \& Lindh, 1996). Pressures of 10-12 kbar (possibly an over-estimate) and temperatures around $630^{\circ} \mathrm{C}$ were obtained for one locality in zone 3 (Söderlund, Söderlund, Möller, Gorbatschev, \& Rodhe, 2004). Water-undersaturated partial melting of metagabbro in zones 7 and 8, needed to produce peritectic pyroxene, indicates temperatures at or above $\sim 850{ }^{\circ} \mathrm{C}$ for the westernmost zones, 7 and 8 (Hansen et al., 2015), i.e. higher than the reported estimates. 
Pressures distinctly higher than elsewhere in the Eastern Segment, peaking at $\sim 18 \mathrm{kbar}$ and $870{ }^{\circ} \mathrm{C}$ (Tual et al., 2017), have been estimated for the eclogite-bearing nappe. The eclogite-facies assemblages and their subsequent granulite-facies overprint demonstrate that this terrane was tectonically emplaced as a nappe or thrust sheet into its present position at 10 kbar, i.e. in the interior of a double crust (Möller, 1998; Möller et al., 2015). It is not known how much the crust had thickened before emplacement of the eclogite-bearing nappe, but the main ductile deformation and recrystallization, corresponding to the regional deformation and metamorphic zoning illustrated in Figures 3 and 9, took place more or less simultaneously with the emplacement of the eclogite-bearing nappe.

The metamorphic field gradient in the Eastern Segment represents higher pressures and temperatures (from $\sim 550{ }^{\circ} \mathrm{C}$ to $\sim 850{ }^{\circ} \mathrm{C}$, and $\sim 9-11 \mathrm{kbar}$ ) than the classic Barrovian field gradient in the Scottish Highlands (Barrow, 1912; Vorhies \& Ague, 2011). The assemblages recorded by Fe-Ti-rich metagabbro in the Eastern Segment, documented in this paper, define a metamorphic field gradient that approaches, but does not quite reach into, ultra-high temperature metamorphic conditions.

\subsubsection{Fluids and partial melts}

The presence of 'dry' and 'wet' assemblages in the same area reflects an uneven distribution of hydrous fluids. Probably, some of these differences were present already prior to the Sveconorwegian orogeny. Many of the intrusive protoliths have originally low contents of hydrous minerals, whereas e.g. slivers of metavolcanic rocks may have been hydrated. Moreover, in western areas local enrichment of $\mathrm{CO}_{2}$-rich fluids is associated with $1.4 \mathrm{Ga}$ intrusions (Harlov, Johansson, van den Kerkhof, \& Förster, 2006; Rimsa, Johansson, \& Whitehouse, 2007). $\mathrm{H}_{2} \mathrm{O}$-rich fluid was, however, demonstrably introduced into dry gabbro during Sveconorwegian deformation (Beckman et al., 2017). In the lower grade zones 1-3, such hydrous fluids were necessary for metamorphic recrystallization of felsic and mafic rocks and are spatially associated with deformation zones (Figure 4a). In the higher-grade zones 4-5 the presence of hydrous fluids assisted and enhanced partial melting, and in the highest-grade zones hydrous fluids have been interpreted to control the type of partial melting (Hansen et al., 2015). It is hypothesized that the combined primary igneous and preSveconorwegian fluid state (fluid deficient, $\mathrm{CO}_{2}$-dominated, or $\mathrm{H}_{2} \mathrm{O}$-dominated) and the Sveconorwegian syn-metamorphic infiltration of hydrous fluids contributed both to the observed variations in mineral assemblage ('wet' or 'dry') and the variations in migmatization within the internal section (zones 4-8).

In situ leucosome is present in both felsic and mafic rocks throughout zones 4-6 (Figures 6 and 7; Andersson, Söderlund, Johansson, \& Möller, 1999, Andersson et al., 2002; Hansen et al., 2015; Möller et. al, 2007, 2015; Pinan-Llamas, Andersson, Möller, Johansson, \& Hansen, 2015). Leucosome is generally absent in undeformed and weakly deformed rocks and instead associated with foliation and folding, forming patch, dilation, stromatic, and net structures. Garnet-bearing leucosome is widespread in garnet amphibolite, but the relative amounts of garnet growth prior to and during partial melting in different rocks are not known. Leucosome in felsic gneisses is, however, generally devoid of peritectic phases; an exception is hornblende in quartz-monzonitic migmatite. Field relations suggesting that water-present partial melting was dominant in felsic rocks are: 1) the association with deformation, inducing pathways for fluids, 2) hornblende and biotite as the dominant ferromagnesian minerals in migmatitic rocks, and 3) the first appearance of leucosome in felsic gneiss and amphibolite at approximately the same location. 
In zones 7-8 the felsic gneisses more commonly have pyroxene-bearing assemblages (Figures 7e,f) and are on average less affected by Sveconorwegian migmatization than in zones 4-6; locally, clinopyroxene occurs in granitic-granodioritic migmatite. Migmatitic garnet amphibolite is abundant, and occurrences of megablastic pyroxene and giant garnet in garnet amphibolite are interpreted to have formed by waterundersaturated partial melting.

Bulk chemical data of felsic orthogneisses, both migmatitic and non-migmatitic varieties, throughout the Eastern Segment (Swedish Geological Survey database) record that the rocks in the Eastern Segment are not restitic and were not depleted or significantly modified by Sveconorwegian partial melting. Rather, melt appears to have largely remained where it was produced. Zircon inheritance in leucosome within a variety of rocks (protoliths 1.7, 1.4 and $1.2 \mathrm{Ga}$, respectively; op. cit.) points to an in situ source, which indicates that mixing of different melt sources, and implicitly melt mobility, was restricted (pegmatites excepted).

\subsection{3 | Deformation}

The deformation pattern shows that the underthrusting plate started to deform in a semipenetrative manner beginning in zone 1 , at $\sim 550-600^{\circ} \mathrm{C}$. At the temperatures attained in zone 3 (roughly at $\sim 650^{\circ} \mathrm{C}$ ) and higher, in the transitional and internal sections, the rocks were highly ductile and penetratively deformed. This is evidenced both by field data and the airborne magnetic anomaly pattern (Figure 9). The rocks record near-penetrative gneissic layering, with transposition of early structures and rock contacts into concordance or near concordance with the regional Sveconorwegian fabric. Rock units are semi-coherent, e.g. an augen gneiss body outlining the boundary of the eclogite-bearing nappe is still recognizable (Möller et al., 2015). The gneissic layering was folded into km-scale recumbent and inclined folds, and by later generations of upright folds (Andersson et al., 1999; Möller et al., 2007, 2015; Pinan-Llamas et al., 2015; Tual et al., 2015). Linear E-W stretching structures developed parallel to the fold axes of early generation folds (D2, op.cit). In several places, the fold limbs have been sheared-out, from outcrop to the kilometre scale, also seen in the airborne magnetic pattern (Figure 9). In the transitional and internal sections, development of the penetrative metamorphic layering and tight folds was broadly coeval with tectonic emplacement of the eclogite-bearing fold nappe, under highly ductile conditions and, in the internal section, in the general presence of partial melt. The timing of this deformation is bracketed between zircon dates of eclogitization at $0.99 \mathrm{Ga}$ and melt crystallization in migmatite at 0.98-0.97 Ga (Table 1). Together, these data demonstrate that the deeply buried parts of the underthrusting plate behaved in a highly ductile manner.

The metamorphic assemblages in deformed rocks can be linked to axial-planar fabrics associated with tight (D2) upright to recumbent folding of the regional gneissosity. Metamorphic isograds are therefore expected to cross the regional gneissosity; this appears to be the case in the metamorphic map presented here (Figure 3), but remains to be demonstrated in detail.

\section{$5.2 \mid$ The tectonic context}

\subsubsection{The relation between the lower and upper plates}

The disparate pre-1.00 Ga orogenic evolutions on either side of the Mylonite Zone (Figure 1) bear witness of its role as a $c .1 .00 \mathrm{Ga}$ crustal amalgamation zone. Evidence that the western terranes were not in their present positions prior to $1.00 \mathrm{Ga}$ includes: 
(1) Crustal blocks on either side of the $\mathrm{MZ}$ differ in protolith age, composition, and preSveconorwegian tectonothermal evolution (Andersson et al., 2002; Petersson et al., 2013; Petersson, Scherstén, Bingen, Gerdes, \& Whitehouse, 2015). West of the MZ are mainly calc-alkaline belts, formed and variously reworked during the 1.64-1.52 Ga Gothian, and 1.52-1.47 Ga Telemarkian, accretionary orogenies (Bingen et al., 2008a). East of the MZ are alkali-calcic rocks of the 1.86-1.66 Ga Transscandinavian Igneous Belt, in the south locally overprinted by $1.47-1.38 \mathrm{Ga}$ metamorphism and associated magmatism during Hallandian orogenesis (Ulmius et al., 2015).

(2) The Sveconorwegian evolutions of the western Sveconorwegian terranes and the Eastern Segment are distinctly different. Whereas the western terranes were metamorphosed during a main Sveconorwegian stage beginning at $1.05 \mathrm{Ga}$ (Bingen et al., 2008b) and progressing for c. $50 \mathrm{Ma}$ together with granite magmatism, the first record of orogeny in the Eastern Segment is prograde metamorphism in eclogite (c. $1000 \mathrm{Ma}$; Andersson, Tual, \& Möller, 2017), reaching eclogite-facies at $0.99 \mathrm{Ga}$. Throughout the Eastern Segment the regional metamorphism and deformation is dated at $0.98-0.97 \mathrm{Ga}$ (Figure 2; Table 1 with references).

(3) The occurrence of the 0.99 Ga eclogite-bearing nappe just below the MZ (Figure 1). This terrane is a metamorphosed slice of the Eastern Segment that was partly exhumed from $~ 65$ $\mathrm{km}$ depth and stalled at $40 \mathrm{~km}$ depth within the orogen (Möller et al., 2015; Tual et al., 2015, 2017).

(4) Pre- and post-collisional magmatism in the western Sveconorwegian terranes at 1.07-1.02 $\mathrm{Ga}$ and 0.95-0.92 Ga, respectively, suggests significant mantle involvement under these terranes (Figure 1; e.g. Brueckner, 2009). In contrast, analogous magmatism is absent in the Eastern Segment and the eastern continuation of Baltic crust: magmatic activity is limited to a post-collisional 0.97-0.92 Ga dolerite dyke swarm intruding during E-W extension, and contemporaneous pegmatite dykes in the internal section of the Eastern Segment.

\subsubsection{Tectonic interpretation}

The differences outlined above (1-4, section 5.2.1) justify the distinction between continental Baltica and the western Sveconorwegian terranes west of the MZ. Following Brueckner (2009), we use the name Sveconorwegia for the western Sveconorwegian terranes (cp. figure 13 in Möller et al., 2015).

The main Sveconorwegian phase in Sveconorwegia at 1.05-1.02 Ga involved metamorphism and deformation, including migmatization, and granite formation. This convergent phase could have been caused by east-dipping subduction of oceanic lithosphere attached to a plate at the present west of Sveconorwegia, but the geological data (points 1-4 above) rather suggest west-dipping subduction and underthrusting beneath Sveconorwegia by Baltican oceanic and continental lithosphere. The final collision of Sveconorwegia with Baltica at $1.0 \mathrm{Ga}$ caused thorough reworking and high-grade metamorphism of the Eastern Segment and the adjacent basal levels of Sveconorwegia. Eclogite records burial of Baltica at $\sim 65 \mathrm{~km}$ depth beneath Sveconorwegia at $0.99 \mathrm{Ga}$ (Möller et al., 2015; Tual et al., 2017). The earliest metamorphic stage, recorded in garnet cores of eclogite, took place under amphibolite-facies conditions corresponding to an elevated geotherm. This earliest metamorphic stage may reflect underthrusting and heating of Baltican crust beneath previously heated Sveconorwegian crust. Rapid tectonic burial to eclogite-facies depths beneath the doubly thickened mountain chain, followed by rapid exhumation, are suggested by steep compression and decompression paths (Figure 8d). In the Eastern Segment there are 
no relicts of UHP assemblages or $\mathrm{Mg}$-Cr peridotite fragments which would be a clear signal of continental subduction into the mantle. A few occurrences of ultramafic rocks carrying remnants of igneous olivine, pyroxene and amphibole (C. Möller, J. Andersson, \& L. Johansson, unpublished data) are possibly tectonic intercalations of wet mantle fragments or lower crustal portions from beneath Sveconorwegia.

The bedrock exposed in the internal section of the Eastern Segment was tectonically buried, principally in situ, at $\sim 40 \mathrm{~km}$ depth. Present-day crustal thickness beneath the Eastern Segment is 38-44 km (Grad, Tiira, \& ESC Working Group, 2009; cp. figure 13 of Stephens \& Andersson, 2015). As no tectonic thickening has affected the bedrock after 0.98 $\mathrm{Ga}$, this value of crustal thickness confirms that the exposed bedrock originated as preSveconorwegian upper-middle crust. By implication, the total orogenic crustal thickness during Sveconorwegian orogeny would have approached $80 \mathrm{~km}$, a value similar to that of the present Himalayas, requiring doubly thickened continental crust. The collision caused crustal underthrusting, $0.99 \mathrm{Ga}$ eclogitization, and 0.98-0.97 Ga high-grade metamorphism and penetrative deformation of the Eastern Segment. Magmatism was absent, in accordance with its tectonic setting as the lower plate of a collisional orogen.

It is likely that there once was supracrustal cover above the crystalline basement of Baltica (i.e. above the Eastern Segment and eastwards). The exposure level of the Eastern Segment, west of the Sveconorwegian Front (Figure 3), is too deep for any cover to be preserved. Remnants of clastic sedimentary rocks are, however, present east of the Sveconorwegian Front, in the Almesåkra Group, and these rocks were folded and thrusted under sub-greenschist conditions (Rodhe, 1987; cp. also Rodhe, 1988). With the exception of the Almesåkra rocks, the once-present Sveconorwegian orogenic prism must have been extruded (thrust) eastwards during the progression of continental collision, unconsolidated cover scraped off, and removed by erosion.

While the Eastern Segment represents the lower plate of a continental collision zone, the western Sveconorwegian terranes represent the upper plate in the hinterland. Possibly, Sveconorwegia is the remnant of an orogenic plateau in which high- and low-grade metamorphic terranes have been tectonically juxtaposed both by shortening and extension. Westward subduction of crust beneath the western Sveconorwegian terranes induced postcollisional anorthosite-mangerite-charnockite-granite magmatism (Brueckner, 2009). Extension at $0.97-0.92 \mathrm{Ga}$ caused intrusion of a major mafic dyke swarm in the eastern part of the orogen and its foreland (Figure 1a), and readjustment along deformation zones between Sveconorwegian terranes.

\subsection{Lower continental plate behaviour}

\subsubsection{Overview comparison with the Himalayas}

Profiles in Figure 10 allow a comparative overview, at the same scale, between the Himalaya-Tibetan and the Sveconorwegian Orogens. One major difference is the level of exposure (dashed blue line in Figure 10b), making the lower continental plate accessible in the eastern Sveconorwegian Orogen and the orogenic prism accessible in the Himalayan. For comparison, the location of the Sveconorwegian Front (greenschist-facies conditions) is inferred to be approximately equivalent to the basement at 10-15 km depth beneath the Main Central Thrust in the Himalayas (Figure 10), and the location of the Almesåkra Group corresponds to the orogenic wedge $20-40 \mathrm{~km}$ farther towards the foreland. Sveconorwegian metamorphism and associated deformation of the lower continental plate closer to the orogenic centre, the Eastern Segment (Figures 3-9), took place following significant 
continental underthrusting beneath Sveconorwegia, the latter already heated, metamorphosed and intruded by granite. The setting of the Eastern Segment is thus broadly comparable to that of the Indian lower plate of the Himalaya-Tibetan Orogen. In detail, however, comparison is difficult, partly because of great differences in erosion level but also because the Himalayan Orogen is still converging whereas the Sveconorwegian Orogen has gone to completion. The airborne magnetic anomaly map of the Eastern Segment (Figure 9) and the metamorphic zoning (Figure 3) are frozen images of the mid-upper part of the underthrusting plate at $0.98-0.97 \mathrm{Ga}$ when the orogen passed from collision to $\mathrm{E}-\mathrm{W}$ extension, an eclogite bearing nappe had just been partially exhumed, and the crust was hot, partially molten, and ductilely deforming. This stage has not yet been reached in the Himalaya-Tibetan Orogen (cp. Searle , Elliott, Phillips, \& Chung, 2011). Eclogite exhumation, ductile deformation of hot partially molten crust, and extrusion are ongoing processes in the Himalayan orogenic wedge (Lesser and Greater Himalayas, Tehyan sequences), but the Indian lower crust may well be in a metastable unmetamorphosed state $200 \mathrm{~km}$ north of the Main Frontal Thrust.

\subsubsection{The lower continental plate: a distinct metamorphic system}

With the exception of the eclogite-bearing nappe, mafic rocks in the Eastern Segment record a distinct event of metamorphic recrystallization at $0.98-0.97 \mathrm{Ga}$ linked to deformation and infiltration of hydrous fluids. Unzoned or weakly prograde-zoned garnet porphyroblasts in metagabbroic rocks record little or no prograde metamorphism (Söderlund et al., 2004; Wang $\&$ Lindh, 1996). Likewise, coronitic textures and remnants of igneous minerals are locally preserved in metagabbro even in the highest-grade zones 6-8 (e.g., Figures 6e,f and 7d). Metamorphic zircon in non-migmatitic metagabbro and zircon in migmatitic garnet amphibolite in the highest-grade zone record ages of 0.98-0.97 Ga (Table 1; Figure 2). Although present data are limited, they indicate that dry portions of the basement remained metastable, in either a pristine igneous or a pre-Sveconorwegian $1.4 \mathrm{Ga}$ metamorphic state, throughout the collisional stage at $0.99 \mathrm{Ga}$. Similar metastable persistence of 'dry' igneous rocks has been documented in thrust sheets at various tectonostratigraphic levels in the Scandinavian Caledonides (e.g., Austrheim, 1987, 2013).

The Eastern Segment also provides information on the behaviour of partial melt and the rheology of the lower plate. Although syntectonic partial melting at $0.98-0.97 \mathrm{Ga}$ was widespread in the internal section, melts appear to have stayed largely in situ. The structural state at the 30-40 km level demonstrates high-temperature ductile flow with disruption of competent rocks, while still preserving large-scale lithological coherence.

The eclogite-bearing nappe in the Sveconorwegian Orogen, extruded from the deeper interior of the collision zone, records not only a tectonometamorphic break to its surroundings, but also a $P-T$ path involving both prograde and retrograde metamorphism (Möller, 1998, 1999; Möller et al., 2015; Tual et al., 2017). Thus, while the data reported herein from the Eastern Segment suggest that metastable persistence and short-lived metamorphism characterize underthrusting continental plates down to $\sim 40 \mathrm{~km}$, they also show that the deepest buried and eclogitized continental crust in the collision zone may experience a more extended history of re-equilibration, though still commencing with recrystallization first at $600-650{ }^{\circ} \mathrm{C}$.

Collectively the features in the Eastern Segment suggest that, although responding by highly ductile deformation at an advanced stage of collision, a large tract of the underthrusting plate remained coherent and did not undergo metamorphic recrystallization until temperatures of $\sim 600{ }^{\circ} \mathrm{C}$ were reached. This is in line with geophysical 
data suggesting structural coherence of the Indian plate beneath the Himalayas (Zhao et al., 1993).

Hydrous fluid is abundant in most metamorphic systems, e.g. metamorphosed sedimentary wedges and subduction zones. Permeable and hydrated rocks will readily equilibrate and re-equilibrate beginning at comparably low temperature and throughout the progression of metamorphism. The data reported above from the Eastern Segment bear witness of that continental bedrock of intrusive igneous origin makes for a metamorphic system that is quite different from orogenic wedges, subduction zones, and arcs. The differences between 'dry' and hydrous crust govern not only the rheology of the metamorphosed crust (e.g., Austrheim, 1987, 2013; Gerbi, Culshaw, \& Marsh, 2010), but also metamorphic reactions and micro-scale processes in the rocks, including the formation of minerals used for age determination, e.g. zircon. Assumption of continuous equilibration throughout a $P-T$ path may be appropriate for water-saturated metamorphic environments (orogenic wedges, subduction zones), whereas metastable persistence and fluid-induced reaction is expected in 'dry' metamorphic environments (igneous crust). These differences between 'dry' and hydrous bedrock ultimately affect not only the rheology of large-scale tectonic systems, but also how we should interpret the metamorphic rock records.

\section{ACKNOWLEDGEMENTS}

Thirty years of research, ultimately allowing the compilation of this paper, has been supported by grants from (in chronological order) the Swedish Research Council (1990's), the Geological Survey of Sweden (2004-2015), the Crafoord Foundation (2011-2015), and the Royal Swedish Academy of Science (2014), and would not have been possible without the opportunity to participate in the bedrock mapping program of the Geological Survey of Sweden in SW Sweden. Our research has benefitted from collaboration and interaction over 30 years with many colleagues, too many to name here, at the Department of Geology, Lund University, at other universities, and the Geological Surveys of Sweden and Norway, as well as with MSc and PhD students at the Department of Geology, Lund University. We gratefully acknowledge everyone. L. Johansson is thanked for reading an early draft of the manuscript. Insightful reviews by R. Jamieson and T. Rivers have improved the paper.

\section{REFERENCES}

Andersson, J., Söderlund, U., Johansson, L., \& Möller, C. (1999). Sveconorwegian (Grenvillian) deformation, metamorphism and leucosome formation in SW Sweden, SW Baltic Shield: constraints from a Mesoproterozoic granite intrusion. Precambrian Research, 98, 151-171.

Andersson, J., Möller, C., \& Johansson, L. (2002). Zircon chronology of migmatite gneisses along the Mylonite Zone (S. Sweden): a major Sveconorwegian terrane boundary in the Baltic Shield. Precambrian Research, 114, 121-147.

Andersson, J., Tual, L., \& Möller, C. (2017). A U-Pb and REE zircon record of the prograde metamorphic evolution of eclogitized crust - an example from the Eastern Segment, Sveconorwegian orogen. Abstract, $12^{\text {th }}$ International Eclogite Conference, Sweden, August 2017. To be submitted within the nearest months as a journal paper.

Andréasson, P.-G., \& Rodhe, A. (1990). Geology of the Protogine zone south of Lake Vättern, southern Sweden; a reinterpretation. Geologiska Föreningens i Stockholm Förhandlingar, 112, 107-125.

Austin Hegardt, E.A., Cornell, D., Claesson, L., Simakov, S., Stein, H., \& Hannah, J. (2005). Eclogites in the central part of the Sveconorwegian Eastern Segment of the Baltic Shield: Support for an extensive eclogite terrane. GFF, 127, 221-232. 
Austrheim, H. (1987). Eclogitization of lower crustal granulites by fluid migration through shear zones. Earth and Planetary Science Letters, 81, 221-232.

Austrheim, H. (2013). Fluid and deformation induced metamorphic processes around Moho beneath continent collision zones: Examples from the exposed root zone of the Caledonian mountain belt, W-Norway. Tectonophysics, 609, 620-635.

Barrow, G. (1912). On the geology of the lower Deeside and the southern highland border. Proceedings of the Geologists Association, 23, 268-284.

Beckman, V., Möller, C., Söderlund, U., \& Andersson, J. (2017). Zircon growth during progressive metamorphic recrystallization of gabbro to garnet amphibolite, Eastern Segment, Sveconorwegian orogen. Journal of Petrology, 58, 167-187.

Bethune, K.M., \& Davidson, A. (1997). Grenvillian metamorphism of the Sudbury diabase dyke-swarm: from protolith to two-pyroxene-garnet coronite. Canadian Mineralogist, 35, 1191-1220.

Bingen, B., Andersson, J., Söderlund, U., \& Möller, C. (2008a). The Mesoproterozoic in the Nordic countries. Episodes, 31, 29-34.

Bingen, B., Nordgulen, Ø., \& Viola, G. (2008b). A four-phase model for the Sveconorwegian orogeny, SW Scandinavia. Norwegian Journal of Geology, 88, 43-72.

Brander, L., \& Söderlund, U. (2009). Mesoproterozoic (1.47-1.44 Ga) orogenic magmatism in Fennoscandia; Baddeleyite U-Pb dating of a suite of massif-type anorthosite in S. Sweden. International Journal of Earth Sciences, 98, 499-516.

Brander, L., Appelqvist, K., Cornell, D., \& Andersson, U.B. (2012). Igneous and metamorphic geochronologic evolution of granitoids in the central Eastern Segment, southern Sweden. International Geology Review, 54, 505-546.

Brown, D, van Gool, J., Calon, T., \& Rivers, T. (1991). The geometric and kinematic development of the Emma Lake thrust stack, Grenville Front, southwestern Labrador. Canadian Journal of Earth Sciences, 28, 136-144.

Brueckner, H. (2009). Subduction of continental crust, the origin of post-orogenic granitoids (and anorthosites?) and the evolution of Fennoscandia. Journal of the Geological Society of London, 166, 753-762.

Cawood, P.A., Nemchin, A.A., Strachan, R., Prave, T., \& Krabbendam, M. (2007). Sedimentary basin and detrital zircon record along East Laurentia and Baltica during assembly and breakup of Rodinia. Journal of the Geological Society of London, 164, $257-$ 275.

Christoffel, C., Connelly, J.N., \& Åhäll, K.-I. (1999). Timing and characterization of recurrent pre-Sveconorwegian metamorphism and deformation in the Varberg-Halmstad region of SW Sweden. Precambrian Research, 98, 173-195.

Coint, N., Slagstad, T., Roberts, N. M. W., Marker, M., Røhr, T., \& Sørensen, B. E. (2015). The Late Mesoproterozoic Sirdal Magmatic Belt, SW Norway: relationships between magmatism and metamorphism and implications for Sveconorwegian orogenesis. Precambrian Research, 265, 57-77.

Connelly, J.N., Berglund, J., \& Larson, S. (1996). Thermotectonic evolution of the Eastern Segment of SW Sweden; tectonic constraints from U-Pb geochronology. In: Brewer, T.S. (Ed.), Precambrian Crustal Evolution in the North Atlantic Region. Geological Society Special Publication, 112, 297-313.

Copley, A., Avouac, J.-P., \& Wernicke, B.P. (2011). Evidence for mechanical coupling and strong Indian lower crust beneath southern Tibet. Nature, 472, 79-81.

Craig, T.J., Copley, A., \& Jackson, J. (2012). Thermal and tectonic consequences of India underthrusting Tibet. Earth and Planetary Science Letter, 353-354, 231-239. 
Drake, H., Tullborg, E.-L., \& Page, L.M. (2009). Distinguished multiple events of fracture mineralisation related to far-field orogenic effects in Paleoproterozoic crystalline rocks, Simpevarp area, SE Sweden. Lithos, 110, 37-49.

Engvik, A.K., Bingen, B., \& Solli, A. (2016). Localized occurrences of granulite: P-T modeling, $\mathrm{U}-\mathrm{Pb}$ geochronology and distribution of early-Sveconorwegian high-grade metamorphism in Bamble, South Norway. Lithos 240-243, 84-103.

Gee, D.G., Kumpulainen, R., Roberts, D., Stephens, M.B., \& Zachrisson, E. (1985). Scandinavian Caledonides Tectonostratigraphic Map, scale 1:2,000,000. Geological Survey of Sweden Ba 35.

Gerbi, C., Culshaw, N., \& Marsh, J. (2010). Magnitude of weakening during crustal-scale shear zone development. Journal of Structural Geology, 32, 107-117.

Grad, M., Tiira, T., \& ESC Working Group (2009). The Moho depth map of the European Plate. Geophysical Journal International, 176, 279-292.

Hansen, E., Johansson, L., Andersson, J., LaBarge, L., Harlov, D., Möller, C., \& Vincent, S. (2015). Partial melting in amphibolites in a deep section of the Sveconorwegian Orogen, SW Sweden. Lithos, 236, 27-45.

Harlov, D.E., Johansson, L., van den Kerkhof, A., \& Förster, H.-J. (2006). The role of advective fluid flow and diffusion during localized, solid state dehydration: Söndrum Stenhuggeriet, Halmstad, SW Sweden. Journal of Petrology, 47, 3-33.

Hetényi, G., Cattin, R., Brunet, F., Bollinger, L., Vergne, J., Nábělek, J.L., \& Diament, M. (2007). Density distribution of the India plate beneath the Tibetan plateau: geophysical and petrological constraints on the kinetics of lower-crustal eclogitization. Earth and Planetary Science Letters, 264, 226-244.

Indares, A. (1995). Metamorphic interpretation of high-pressure-temperature metapelites with preserved growth zoning in garnet, eastern Grenville Province, Canadian Shield. Journal of Metamorphic Geology, 13, 475-486.

Indares, A., \& Rivers, T., (1995). Textures, metamorphic reactions and thermobarometry of eclogitized metagabbros: a Proterozoic example. European Journal of Mineralogy, 7, 4356.

Jackson, J.A., Austrheim, H., McKenzie, D., \& Priestley, K. (2004). Metastability, mechanical strength, and the support of mountain belts. Geology (Boulder), 32(7), 625628.

Jackson, J.A., McKenzie, D., Priestley, K., \& Emmerson, B. (2008). New views on the structure and rheology of the lithosphere. Journal of the Geological Society of London, $165,453-465$.

Jamieson, R.A., Unsworth, M.J., Harris, N.B.W., Rosenberg, C.L., \& Schulmann, K. (2011). Crustal melting and the flow of mountains. Elements, 7, 253-260.

Johansson, L., Lindh, A., \& Möller, C. (1991). Late Sveconorwegian (Grenville) highpressure granulite facies metamorphism in southwest Sweden. Journal of Metamorphic Geology, 9, 283-292.

Johansson, L., Möller, C., \& Söderlund, U. (2001). Geochronology of eclogite facies metamorphism in SW Sweden. Precambrian Research, 106, 261-275.

Johnson, M.R.W., \& Harley, S.L. (2012). Orogenesis. The making of Mountains. Cambridge University Press. 388 pp.

Krogh, T. E., Kamo, S. L., Robinson, P., Terry, M. P.\& Kwok, K. (2011). U-Pb zircon geochronology of eclogites from the Scandian Orogen, northern Western Gneiss Region, Norway: 14-20 million years between eclogite crystallization and return to amphibolitefacies conditions. Canadian Journal of Earth Sciences, 48, 441-472.

Laurent, A. T., Seydoux-Guillaume, A. M., Duchene, S., Bingen, B., Bosse, V., \& Datas, L. (2016). Sulphate incorporation in monazite lattice and dating the cycle of sulphur in

This article is protected by copyright. All rights reserved. 
metamorphic belts. Contributions to Mineralogy and Petrology, 171, 94. DOI 10.1007/s00410-016-1301-5.

Li, Z.X., Bogdanova, S.V., Collins A.S., Davidson, A., De Waele, B., Ernst, R.E., Fitzsimons, I.C.W., Fuck, R.A., Gladkochub, D.P., Jacobs, J., Karlstrom, K.E., Lu, S., Natapov, L.M., Pease, V., Pisarevsky, S.A., Thrane, K., \& Vernikovsky, V. (2008). Assembly, configuration, and break-up history of Rodinia: A synthesis. Precambrian Research, 160, 179-210.

Lundqvist, I., Eliasson, T., Hellström, F. \& Austin Hegardt, E. (2007): U-Pb zircon geochronology of a gneissic granite in a WNW trending deformation zone in southern Halland, eastern Sveconorwegian Province. In F. Hellström \& J. Andersson (eds.): Results from radiometric datings and other isotope analyses 1. Geological Survey of Sweden Open File Report 2007:28, p. 25-26.

Möller, C. (1998): Decompressed eclogites in the Sveconorwegian (-Grenvillian) orogen of SW Sweden: Petrology and tectonic implications. Journal of Metamorphic Geology, 16, 641-656.

Möller, C. (1999). Sapphirine in SW Sweden; a record of Sveconorwegian (-Grenvillian) late-orogenic tectonic exhumation. Journal of Metamorphic Geology, 17, 127-141.

Möller, C., \& Söderlund, U. (1997). Age constraints on the regional deformation within the Eastern Segment, S. Sweden: Late Sveconorwegian granite dyke intrusion and metamorphic-deformational relations. GFF, 119, 1-12.

Möller, C., Andersson, J., Lundqvist, I., \& Hellström, F. (2007). Linking deformation, migmatite formation and zircon U-Pb geochronology in polymetamorphic orthogneisses, Sveconorwegian Province, Sweden. Journal of Metamorphic Geology, 25, 727-750.

Möller, C., Andersson, J., Dyck, B., \& Lundin, I. A. (2015): Exhumation of an eclogite terrane as a hot migmatitic nappe, Sveconorwegian orogen. Lithos, 226, 147-168.

Nábělek, J.L., Hetényi, G., Vergne, J., Sapkota, S., Kafle, B., Jiang, M., Su, H., Chen, J., Huang, B.S., \& Hi-CLIMB Team (2009). Underplating in the Himalaya-Tibet collision zone revealed by the Hi-CLIMB experiment. Science, 325, 1371-1374.

Nelson, K D., Zhao, W., Brown, L.D., Kuo, J., Che, J., Liu, X., Klemperer, S.L., Makovsky, Y., Meissner, R., Mechie, J., Kind, R, Wenzel, F., Ni, J., Nabelek, J., Leshou, C., Tan, H., Wei, W., Jones, A.G., Booker, J., Unsworth, M., Kidd, W.S.F , Hauck, M., Alsdorf, D., Ross, A., Cogan, M., Wu, C., Sandvol, E., \& Edwards, M. (1996). Partially molten middle crust beneath southern Tibet: synthesis of project INDEPTH results. Science, 274, 1684-1687.

Nolte, N., Kleinhanns, I. C., Baero, W., \& Hansen, B. T. (2011). Petrography and whole-rock geochemical characteristics of Västervik granitoids to syenitoids, southeast Sweden: constraints on petrogenesis and tectonic setting at the southern margin of the Svecofennian domain. GFF, 133, 173-196.

Page, L.M., Möller, C., \& Johansson, L. (1996). ${ }^{40} \mathrm{Ar} /{ }^{39} \mathrm{Ar}$ geochronology across the Mylonite Zone and the Southwestern Granulite province in the Sveconorwegian Orogen of $\mathrm{S}$ Sweden. Precambrian Research, 79, 239-259.

Petersson, A, Scherstén, A., Andersson, J., \& Möller, C. (2013). Zircon U-Pb and Hf isotopes from the eastern part of the Sveconorwegian Orogen, SW Sweden: implications for the growth of Fennoscandia. Geological Society of London Special Publications, 389, 281-303.

Petersson, A., Scherstén, A., Bingen, B., Gerdes, A., \& Whitehouse, M.J. (2015). Mesoproterozoic continental growth: U-Pb-Hf-O zircon record in the Idefjorden Terrane, Sveconorwegian Orogen. Precambrian Research, 261, 75-95. 
Pinan-Llamas, A., Andersson, J., Möller, C., Johansson, L., \& Hansen, E. (2015). Polyphasal foreland-vergent deformation in a deep section of the $1 \mathrm{Ga}$ Sveconorwegian orogen. Precambrian Research, 265, 121-149.

Rimsa, A., Johansson, L., \& Whitehouse, M.J. (2007). Constraints of incipient charnockite formation from zircon geochronology and rare earth element characteristics. Contributions to Mineralogy and Petrology, 154, 357-369.

Rivers, T. (2008). Assembly and preservation of lower, mid and upper orogenic crust in the Grenville Province - Implications for the evolution of large hot long-duration orogens. Precambrian Research, 167, 237-259.

Rivers, T., Culshaw, N., Hynes, A., Indares, A., Jamieson, R., \& Martignole, J. (2012). The Grenville orogen - A post-Lithoprobe perspective. Chapter 3, in: Percival, J.A., Cook, F.A., Clowes, R.M. (Eds.), Tectonic Styles in Canada: The LITHOPROBE perspective. Geological Association of Canada Special Paper, 49, 97-236.

Robinson, P., Roberts, D., Gee, D.G., \& Solli, A. (2013). A major synmetamorphic Early Devonian thrust and extensional fault system in the Mid Norway Caledonides: relevance to exhumation of HP and UHP rocks. Geological Society of London Special Publications, 390, 241-270.

Rodhe, A. (1987). Depositional environments and lithostratigraphy of the Middle Proterozoic Almesåkra group, southern Sweden. Sveriges Geologiska Undersökning, Ca 69, 1-80.

Rodhe, A. (1988). The dolerite breccia of Tärnö, Late Proterozoic of southern Sweden. GFF, 110, 131-142.

Saintot, A., Stephens, M.B., Viola, G., \& Nordgulen, Ø. (2011): Brittle tectonic evolution and paleostress field reconstruction in the southwestern part of the Fennoscandian Shield, Forsmark, Sweden. Tectonics, 30, TC4002, doi:10.1029/2010TC002781.

Schulte-Pelkum, V., G. Monsalve, A. Sheehan, M.R. Pandey, S. Sapkota, R. Bilham \& F. Wu (2005). Imaging the Indian Subcontinent beneath the Himalaya, Nature, 435, 1222-1225.

Searle, M.P., Cottle, J.M., Streule, M.J., \& Waters, D.J. (2010). Crustal melt granites and migmatites along the Himalaya: melt source, segregation, transport and granite emplacement mechanisms. Transactions of the Royal Society of Edinburgh, 100, 219-233.

Searle, M.P., Elliott, J.R., Phillips, R.J., \& Chung, S.-L. (2011). Crustal-lithospheric structure and continental extrusion of Tibet. Journal of the Geological Society, 168, 633-672.

Söderlund, P., Söderlund, U., Möller, C., Gorbatschev, R., \& Rodhe, A. (2004). Petrology and ion microprobe $\mathrm{U}-\mathrm{Pb}$ chronology applied to a metabasic intrusion in southern Sweden: A study on zircon formation during metamorphism and deformation. Tectonics, 23, 1-16.

Söderlund, U. (1996). Conventional U-Pb dating versus single-grain $\mathrm{Pb}$ evaporation dating of complex zircons from a pegmatite in the high-grade gneisses of southwestern Sweden. Lithos, 38(1), 93-105.

Söderlund, U., \& Ask, R. (2006). Mesoproterozoic bimodal magmatism along the Protogine Zone, S Sweden: three magmatic pulses at $1.56,1.22$ and $1.205 \mathrm{Ga}$, and regional implications. GFF, 128, 303-310.

Söderlund, U., Hellström, F. A., \& Kamo, S. L. (2008a). Geochronology of high-pressure mafic granulite dykes in SW Sweden: tracking the P-T-t path of metamorphism using Hf isotopes in zircon and baddeleyite. Journal of Metamorphic Geology, 26, 539-560.

Söderlund, U., Karlsson, C., Johansson, L., \& Larsson, K. (2008b). The Kullaberg peninsulaa glimpse of the Proterozoic evolution of SW Fennoscandia. GFF, 130, 1-10.

Söderlund, U., Möller, C., Andersson, J., Johansson, L., \& Whitehouse, M. (2002). Zircon geochronology in polymetamorphic gneisses in the Sveconorwegian orogen, SW Sweden: ion microprobe evidence for 1.46-1.42 and 0.98-0.96 Ga reworking. Precambrian Research, 113, 193-225.

This article is protected by copyright. All rights reserved. 
Söderlund, U., Isachsen, C.A., Bylund, G., Heaman, L., Patchett, P.J., Vervoort, J.D. \& Andersson, U.B. (2005). U-Pb baddeleyite ages sand Hf-Nd isotope chemistry constraining repeated mafic magmatism in the Fennoscandian Shield from 1.6 to $0.9 \mathrm{Ga}$. Contributions to Mineralogy and Petrology, 150, 174-194.

Stephens, M.B., \& Andersson, J. (2015). Migmatization related to mafic underplating and intra- or back-arc spreading above a subduction boundary in a 2.0-1.8 Ga accretionary orogen, Sweden. Precambrian Research, 264, 235-257.

Stephens, M.B., Wahlgren, C.-H., Weijermars, R., \& Cruden, A.R. (1996). Left-lateral transpressive deformation and its tectonic implications, Sveconorwegian orogen, Baltic Shield, southwestern Sweden. Precambrian Research, 79, 261-279.

Tual, L., Pinan-Llamas, A., \& Möller, C. (2015). High-temperature deformation in the basal shear zone of an eclogite-bearing fold nappe, Sveconorwegian orogen, Sweden. Precambrian Research, 265, 104-120.

Tual, L., Pinan-Llamas, A., \& Möller, C. (2015). High-temperature deformation in the basal shear zone of an eclogite-bearing fold nappe, Sveconorwegian orogen, Sweden. Precambrian Research, 265, 104-120.

Tual, L., Pitra, P., \& Möller, C. (2017). P-T evolution of Precambrian eclogite in the Sveconorwegian orogen, SW Sweden. Journal of Metamorphic Geology, 35, 493-515.

Ulmius, J., Andersson, J., \& Möller, C. (2015). Hallandian high temperature metamorphism at $1.45 \mathrm{Ga}$ in continent Baltica: $\mathrm{P}-\mathrm{T}$ evolution and SIMS U-Pb zircon ages of aluminous gneisses, SW Sweden. Precambrian Research, 265, 10-39.

Ulmius, J., Möller, C., Page, L., Johansson, L., \& Ganerød, M. (submitted). The eastern boundary of Sveconorwegian reworking in the Baltic Shield, defined by ${ }^{40} \mathrm{Ar} /{ }^{39} \mathrm{Ar}$ geochronology across the southernmost Sveconorwegian Province. Submitted to Precambrian Research June 2017; revision almost completed, soon to be resubmitted.

Unsworth, M.J., Jones, A.G., Wei, W., Marquis, G., Gokarn, S.G., Spratt, J.E, \& the INDEPTH-MT team (2005). Crustal rheology of the Himalaya and southern Tibet inferred from magnetotelluric data. Nature, 438, 78-81.

Vorhies, S., \& Ague, J. (2011). Pressure-temperature evolution and thermal regimes in Barrovian zones, Scotland. Journal of the Geological Society of London, 168, 1147-1166.

Wahlgren, C.-H., Cruden, A.R., \& Stephens, M.B. (1994). Kinematics of a major fan-like structure in the eastern part of the Sveconorwegian Orogen, Baltic Shield, south-central Sweden. Precambrian Research, 70, 67-91.

Wang, X.D., \& Lindh, A. (1996): Temperature-pressure investigation of the southern part of the Southwest Swedish Granulite Region. European Journal of Mineralogy, 8, 51-67.

Wang, X.-D., Söderlund, U., Lindh, A., \& Johansson, L. (1998). U-Pb and Sm-Nd dating of high-pressure granulite- and upper amphibolite facies rocks from SW Sweden.

Precambrian Research, 92, 319-339.

Zhao, W., Nelson, K.D., \& Project INDEPTH Team (1993). Deep Seismic reflection evidence for continental underthrusting beneath southern Tibet. Nature, 366, 557-559.

\section{SUPPORTING INFORMATION}

Additional Supporting Information may be found online in the supporting information tab for this article.

Figure S1. Geographic distribution of bedrock maps and observations points available in database of the Geological Survey of Sweden.

Figure S2. Geographic location map of samples of Fe-Ti-rich metagabbro.

Dataset.xls/x

Table S1. Geographic locations of the rocks illustrated in Figures 4-8. 


\section{FIGURE AND TABLE CAPTIONS}

Figure 1. Tectonic and regional setting. (a) Plate reconstruction at the end of the GrenvillianSveconorwegian orogeny [unpublished compilation by B. Bingen, based on the reconstruction by Cawood, Nemchin, Strachan, Prave, \& Krabbendam, (2007); metamorphic subdivisions following Rivers (2008)]. (b) Schematic representation of continent Baltica, inset to scale (transparent white with the Sveconorwegian orogen in pink), at two alternative positions in a collisional orogen: India-style versus intracontinental underthrusting. Modified from Möller et al. (2015). Composite satellite photograph of Asia in orthographic projection (source: NASA). (c). Tectonic map of the Sveconorwegian orogen (based on Geological Surveys of Sweden and Norway databases; distribution of 1.05-1.02 Ga granites from Laurent et al., 2016), with the Eastern Segment in violet to medium dark grey shades and a schematic cross-section. Internal subdivision of the Eastern Segment after Möller et al. (2015); eclogite-bearing nappe in darkest violet. Red bars mark the location of the schematic cross section (lower right), and the orogenic reconstruction in Figure 10b. Box marks the area in Figures 2, 3 and 9.

Figure 2. Locations of $\mathrm{U}-\mathrm{Pb}$ dates of Sveconorwegian metamorphic and migmatite zircon in the Eastern Segment (sources in Table 1), overlain on softened greyscale airborne magnetic anomaly map (differential field; source: Geological Survey of Sweden).

Figure 3. Metamorphic zones of the Eastern Segment (cp. Figure 1c), overlain on greyscale airborne magnetic anomaly map (differential field; source: Geological Survey of Sweden; softened contrast). Zones 1-8 represent gradually increasing metamorphic grade, from $\sim 550$ ${ }^{\circ} \mathrm{C}$ in the east to $\sim 850{ }^{\circ} \mathrm{C}$ in the west. Metamorphic zones are based on assemblages in $\mathrm{Fe}-\mathrm{Ti}$ rich metagabbro $(n=276)$ of a $\sim 75 \mathrm{~km}$ wide profile between the coastal areas and $130 \mathrm{~km}$ towards ENE; zones are preliminary extrapolated to areas north and south of this profile. The gently west-dipping Mylonite Zone (MZ, red line) is the lithotectonic boundary between the Eastern Segment and the western Sveconorwegian terranes, with the Idefjorden Terrane (shaded orange) positioned structurally immediately above the Eastern Segment.

Sveconorwegian Front (SF) marks the eastern limit of non-penetrative Sveconorwegian deformation and metamorphic recrystallization.

Figure 4. Metamorphism and deformation in zones 1 and 2 (the frontal wedge). (a) Kfeldspar-megacrystic granite transected by $\mathrm{N}-\mathrm{S}$-striking, steeply dipping ductile shear zones (zone 1). (b) Deformed metagabbro, plagioclase-rich in the top upper part of the photo (zone2). (c) Thin section of deformed and metamorphosed gabbro (zone 1) consisting of blue-green hornblende (Am), plagioclase (Pl), biotite, and Fe-Ti-oxide. The domain texture reflects the origin as coarse-to medium-grained gabbro. (d) Thin section of undeformed metagabbro (zone 2), with relict igneous texture and plagioclase laths, and igneous pyroxene grains largely replaced by blue-green amphibole. Fe-Ti-oxide grains are surrounded by biotite; small euhedral garnet crystals, too small to be seen in this overview, occur together with amphibole in the outermost part of the pseudomorphs after pyroxene.

Figure 5. Metamorphism and deformation in zone 3 (the transitional section); (a)-(e) coin, $20 \mathrm{~mm}$, for scale. (c)-(f) are parts of the same metagabbro body. (a) Recrystallized and weakly deformed K-feldspar augen gneiss. Light reddish granitic gneiss, recrystallized and strongly gneissose. (c) Well-preserved coarse-grained gabbro. (d) Garnet-rich coronitic metagabbro. (e) Deformed garnet-rich metagabbro. (f) Thin section of garnet-porphyroblastic amphibolite, consisting of green hornblende, garnet, plagioclase, biotite and Fe-Ti oxide. Figure 6. Metamorphism and deformation in zones 4-6 (the internal section). (a) Stromatic migmatitic gneiss with amphibolite layers. Protolith is $1.68 \mathrm{Ga}$ granite, migmatization is dated at $976 \pm 7 \mathrm{Ma}$. Zone 5 (Cpx). (b) Migmatitic granitic gneiss, protolith is $1.39 \mathrm{Ga}$ granite. Zone $5(\mathrm{Cpx})$. (c) Migmatitic garnet amphibolite with tonalitic leucosome. Zone 4 (olive $\mathrm{Hbl}$ ). (d) Metagabbro with partly preserved igneous clinopyroxene grains (dark), and 
igneous plagioclase laths. The rock is rich in garnet (red) and contains metamorphic clinopyroxene and plagioclase. Zone $5(\mathrm{Cpx})$. (e). Thin section of moderately deformed metagabbro with remnants of igneous clinopyroxene (centres of green domains), rich in finegrained metamorphic clinopyroxene (green), garnet (reddish), antiperhitic plagioclase (white), and orthopyxene (reddish green). Zone 6 (Opx). (f) Thin section of metagabbro with relict coarse-grained igneous texture, completely replaced by metamorphic minerals: clinopyroxene (green), garnet (light red), plagioclase (white), orthopyroxene (reddish-green, intergrown with $\mathrm{Cpx}$ ), biotite (brown), Fe-Ti-oxide (black), and hornblende (olive green). Zone 6 (Opx).

Figure 7. Metamorphism and deformation in zones 7-8 (western internal section). (a) Orthopyroxene-megablast (dark, brownish weathering) in leucosome of garnet amphibolite. Thin coronas of clinopyroxene (green), hornblende (black), and garnet (red, next to leucosome feldspar and quartz) surround the orthopyroxene blast. (b) $10 \mathrm{~cm}$ garnet megablast in migmatitic garnet amphibolte, characteristic of zone 8. (c) Inclusion-rich clinopyroxene blast in leucosome, occurring locally in zone 8 in garnet-porphyroblastic amphibolite. The inclusions in the clinopyroxene blast are composite plagioclase + quartz (inferred tonalitic melt); small patches of hornblende are also present. (d) Garnet coronitic metagabbro in zone 8 , with relict originally coarse-grained igneous texture and remnants of igneous clinopyroxene grains characteristically dusted by Fe-Ti oxide. (e) Gneissic Varberg charnockite (protolith age $1.39 \mathrm{Ga}$ ) with foliae defined by Sveconorwegian metamorphic clinopyroxene, orthopyroxene, garnet, olive-green hornblende, reddish brown biotite, Fe-Ti oxide, plagioclase (partly antiperthite), microperthite, and quartz. (f) Felsic gneiss (protolith age $1.7 \mathrm{Ga}$ ) rich in metamorphic clinopyroxene, and foliae defined by the same mineral assemblage as in the Varberg charnockite (e).

Figure 8. The eclogite-bearing terrane in the Eastern Segment. (a) Migmatitic gneiss with folded stromatic leucosome and amphibolite boudin in the internal part of the eclogitebearing nappe. (b) High-temperature mylonitic gneiss with mafic boudins in the basal shear zone. (c) Thin section of kyanite-, rutile- and corundum-bearing eclogite, partly reequilibrated during decompression, which formed symplectitic (sy) reaction rims of sapphirine, corundum, and anorthite around kyanite, orthopyroxene+plagioclase \pm amphibole symplectite on the rims of clinopyroxene, and plagioclase expulsion in former omphacite. (d) $P-T$ path recorded by the eclogites (Tual, Pitra, \& Möller, 2017). $D_{i}$ represents inclusions in garnet cores and the first record of Sveconorwegian metamorphism, at amphibolite-facies conditions, before tectonic burial at eclogite-facies depth. D1/D2 mark deformation during partial exhumation.

Figure 9. Airborne magnetic anomaly map of the Eastern Segment (source: Geological Survey of Sweden), illustrating the large-scale deformation pattern. The easternmost (less deformed) area is the Transscandinavian Igneous Belt and associated 1.9-1.7 Ga igneous rocks. A $~ 20 \mathrm{~km}$ wide corridor (the frontal wedge) west of the Sveconorwegian Front (SF; dashed white line) is transected by $\mathrm{N}-\mathrm{S}$ trending non-penetrative steeply dipping foliation (cp. Figure 1c). West of the frontal wedge, the gneissic foliation is near-penetrative and polyphasally folded by early recumbent folds with E-W trending fold axes and later upright folds with subhorizontal NE-SW and N-S trending fold axes. Note the presence of isolated fold hinges, entrained between high strain limbs. The lithotectonic boundary between the Idefjorden Terrane and the Eastern Segment (the Mylonite Zone, MZ) is outlined by a solid black line, and the eclogite-bearing nappe (E) shaded white. The Almesåkra Group (A; east of the Sveconorwegian Front) is shown in light yellow. The NW-SE striking lineaments in the south represent the Phanerozoic Tornquist Zone with Permian diabase dykes.

Figure 10. Vertical sections across the frontal parts of the Himalaya-Tibetan and Sveconorwegian Orogens, portrayed at the same horizontal and vertical scale. Violet $=$ 
underthrusting continental crust; light yellow $=$ orogenic prism; orange $=$ overriding continent. Red dashed line $=55 \mathrm{~km}$ depth where mafic rocks transform into eclogite. (a): N-S crosssection across the southern Himalayan-Tibetan Orogen after Searle, Elliott, Phillips, and Chung (2011). STD= South Tibetan Detachment; MCT= Main Central Thrust; MBT= Main boundary Thrust; MFT= Main Frontal Thrust. (b): E-W cross-section across the eastern Sveconorwegian Orogen at the completion of collision at c. $980 \mathrm{Ma}$. The blue dashed line marks the approximate depth of the present erosional surface along the profile marked in Figure 1c. Extruded eclogite-bearing nappe in dark violet; $\mathrm{SF}=\mathrm{Sveconorwegian} \mathrm{Front;} \mathrm{MZ}=$ Mylonite Zone.

Table 1. Table 1. U-Pb zircon dates of Sveconorwegian metamorphic recrystallization and partial melting in the Eastern Segment with numbered references as in Figure 2. Ages are given in Ma, except 6 dates that are based on lower discordia intercepts or on less than four analytical spots; the latter are referred to in Ga. Ages with errors >20 Ma are not included in quoted age intervals in the headings or in the main text.

Table 2. Metamorphic assemblages in Fe-Ti-rich metagabbro, zones 1-8.

This article is protected by copyright. All rights reserved. 
Table 1. U-Pb zircon dates of Sveconorwegian metamorphic recrystallization and partial melting in the Eastern Segment with numbered references as in Figure 2. Ages are given in Ma, except 6 dates that are based on lower discordia intercepts or on less than four analytical spots; the latter are referred to in $\mathrm{Ga}$. Ages with errors $>20 \mathrm{Ma}$ are not included in quoted age intervals in the headings or in the main text.

\begin{tabular}{|c|c|c|c|c|}
\hline \multicolumn{2}{|c|}{ ID in Figure 1 and rock type } & Locality & Age in Ma & \\
\hline \multicolumn{5}{|c|}{ Metamorphic recrystallization of gabbro: $1.00-0.97 \mathrm{Ga}$} \\
\hline \multicolumn{5}{|c|}{ Amphibolite - garnet amphibolite } \\
\hline 1 & Foliated garnet amphibolite & Åker & $1006 \pm 68$ & Söderlund et al. (2004) \\
\hline 2 & Garnet amphibolite & Herrestad & $970 \pm 7$ & Beckman et al. (2017) \\
\hline $3 a$ & Garnet amphibolite & Kånna & $974 \pm 25$ & Wang et al. (1998) \\
\hline \multicolumn{5}{|c|}{ Eclogite } \\
\hline $4 a$ & Isotropic Fe-Ti eclogite & Bollebygd & $985 \pm 4$ & Möller et al. (2015) \\
\hline $4 b$ & Layered Fe-Ti eclogite, incip. melting & Bollebygd & $978 \pm 7$ & Möller et al. (2015) \\
\hline 5 & Kyanite eclogite and Fe-Ti-rich eclogite & Ammås & $1000-970$ & Andersson et al. (2017) \\
\hline 6 & Amphibolite (retrogressed eclogite) & Viared & $936 \pm 40$ & Austin Hegardt et al. (2005) \\
\hline \multicolumn{5}{|c|}{ Crystallization of in situ partial melt: $0.98-0.97 \mathrm{Ga}$} \\
\hline \multicolumn{5}{|c|}{ Garnet amphibolite } \\
\hline $3 b$ & Veined garnet amphibolite & Buskhult & c. $0.97 \mathrm{Ga}$ & Wang et al. (1998) \\
\hline $7 a$ & Migmatitic garnet amphibolite & Stensjöstrand & $970 \pm 4$ & Hansen et al. (2015) \\
\hline $7 \mathrm{~b}$ & Migmatitic garnet amphibolite & Stensjöstrand & $968 \pm 4$ & Hansen et al. (2015) \\
\hline \multicolumn{5}{|c|}{ Granitic gneiss } \\
\hline $4 \mathrm{c}$ & Eclogite bearing stromatic orthogneiss & Målsryd & $976 \pm 6$ & Möller et al. (2015) \\
\hline $8 a$ & Migmatitic augen gneiss & Byasjön & $992 \pm 24$ & Andersson et al. (1999) \\
\hline $9 a$ & Stromatic migmatitic augen gneiss & Tångaberg & $968 \pm 13$ & Andersson et al. (2002) \\
\hline $9 b$ & Eclogite-bearing stromatic migmatitic orthogneiss & Skene skog & $969 \pm 13$ & Andersson et al. (2002) \\
\hline $10 \mathrm{a}$ & Sillimanite-bearing migmatite quartofeldspathic gneiss & Stensjöstrand & $970 \pm 5$ & Piñan-Llamas et al. (2015) \\
\hline $10 b$ & Migmatite quartofeldspathic gneiss & Stensjöstrand & c. $0.97 \mathrm{Ga}$ & Piñan-Llamas et al. (2015) \\
\hline 11a & Syn-kinematic leucosome in stromatic migmatite & Oxanäset & $976 \pm 7$ & Möller et al. (2007) \\
\hline $12 \mathrm{a}$ & Veined leucocratic granitic gneiss & Mårdaklev & c. $0.97 \mathrm{Ga}$ & Söderlund et al. (2002) \\
\hline 20 & Stromatic migmatitic orthogneiss & Vistbergen & c. $0.97 \mathrm{Ga}$ & Connelly et al. (1996) \\
\hline \multicolumn{5}{|c|}{ Crystallization of melt as syn-kinematic veins and dykes: $0.96-0.95 \mathrm{Ga}$} \\
\hline $12 \mathrm{~b}$ & Late kinematic pegmatite & Gällared N & $961 \pm 13$ & Söderlund et al. (2002) \\
\hline $8 b$ & Pegmatitic filling in boudinaged amphibolite & Överlida & $954 \pm 21$ & Andersson et al. (1999) \\
\hline $13 a$ & Leucocratic mobilisate at amphibolite-gneiss contact & Kullaberg & $961 \pm 6$ & Söderlund et al. (2008b) \\
\hline \multicolumn{5}{|c|}{ Metamorphic zircon (unclassified) in deformed felsic rocks: $0.96 \mathrm{Ga}$} \\
\hline 14 & Strongly deformed felsic dyke in eclogite & Ammås & $963 \pm 22$ & Johansson et al. (2001) \\
\hline 10c & Folded and strongly deformed pegmatite & Stensjöstrand & $958 \pm 7$ & Piñan-Llamas et al. (2015) \\
\hline 15 & Migmatitic granitic orthogneiss & Söndrum & c. $0.97 \mathrm{Ga}$ & Rimsa et al. (2007) \\
\hline 16 & Migmatitic granitic orthogneiss & Våxtorp & c. $0.97 \mathrm{Ga}$ & Lundqvist et al. (2007) \\
\hline 17 & Folded and boudinaged pegmatite dyke & Glassvik & $969 \pm 27$ & Söderlund (1996) \\
\hline $18 \mathrm{a}$ & Gneissic aplite-granite dyke & Gällared S & $980 \pm 4^{*}$ & Söderlund et al. (2002) \\
\hline \multicolumn{5}{|c|}{ Post-kinematic pegmatitic and granitic veins and dykes: $0.96-0.93 \mathrm{Ga}$} \\
\hline $11 b$ & Post-kinematic cross-cutting pegmatite dyke & Högabjär & $952 \pm 7$ & Möller et al. (2007) \\
\hline $11 \mathrm{c}$ & Post-kinematic cross-cutting pegmatite dyke & Högabjär & $945 \pm 7$ & Möller et al. (2007) \\
\hline $4 c$ & Post-kinematic leucosome in migmatitic gneiss & Kornarp & $956 \pm 7$ & Möller et al. (2015) \\
\hline $18 b$ & Post-kinematic granitic dyke & Gällared S & $956 \pm 7$ & Möller \& Söderlund (1997) \\
\hline $8 c$ & Post-kinematic cross-cutting pegmatite dyke & Sundhult & $947 \pm 12$ & Andersson et al. (1999) \\
\hline 19 & Post-kinematic cross-cutting pegmatite dyke & Stensjöstrand & $946+6 /-4$ & Christoffel et al. (1999) \\
\hline $13 b$ & Undeformed pegmatite dyke & Kullaberg & $934 \pm 6$ & Söderlund et al. (2008b) \\
\hline
\end{tabular}

* $\mathrm{Pb}-\mathrm{Pb}$ evaporation age

This article is protected by copyright. All rights reserved. 
Table 2. Metamorphic assemblages in Fe-Ti-rich metagabbro, zones 1-8.

\begin{tabular}{|l|l|l|l|l|l|l|l|l|}
\hline Zone & 1 & 2 & 3 & 4 & 5 & 6 & 7 & 8 \\
\hline
\end{tabular}

\begin{tabular}{|c|c|c|c|c|c|c|c|c|}
\hline \multicolumn{9}{|c|}{ Metamorphic assemblages in non-migmatized metagabbro } \\
\hline Blue-green hornblende & $x$ & $X$ & $(X)$ & & & & & \\
\hline Epidote & $x$ & $X$ & $x$ & & & & & \\
\hline Titanite & $X$ & $\mathrm{X}$ & $x$ & $X$ & & & & \\
\hline Plagioclase & $X$ & $X$ & $X$ & $x$ & $X$ & $X$ & $X$ & $X$ \\
\hline Fe-Ti-oxide & $X$ & $x$ & $X$ & $x$ & $x$ & $x$ & $x$ & $X$ \\
\hline Garnet & & $X$ & $X$ & $x$ & $X$ & $X$ & $x$ & $X$ \\
\hline Green hornblende & & & $X$ & $(X)$ & & & & \\
\hline Olive-green hornblende & & & & $X$ & $X$ & $X$ & $X$ & $X$ \\
\hline Rutile & & & & $(X)$ & $(X)$ & $(X)$ & $(?)$ & $(X)$ \\
\hline Clinopyroxene & & & & & $x$ & $X$ & $X$ & 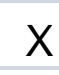 \\
\hline Antiperthite & & & & & & $X$ & $X$ & $x$ \\
\hline Orthopyroxene & & & & & & $\mathrm{X}$ & $x$ & $X$ \\
\hline
\end{tabular}

\begin{tabular}{|l|l|l|l|l|l|l|}
\hline Mineral blasts in le ucosome in migmatitic garnet amphibolite & & \\
\hline Garnet, $0.5-2 \mathrm{~cm}$ & & $X$ & $X$ & $X$ & $X$ & $X$ \\
\hline Orthopyroxene, $2-10 \mathrm{~cm}$ & & & & & $X$ & $X$ \\
\hline Clinopyroxene, $0.5-3 \mathrm{~cm}$ & & & & & $X$ \\
\hline Garnet, $4-20 \mathrm{~cm}$ & & & & & $X$ \\
\hline
\end{tabular}




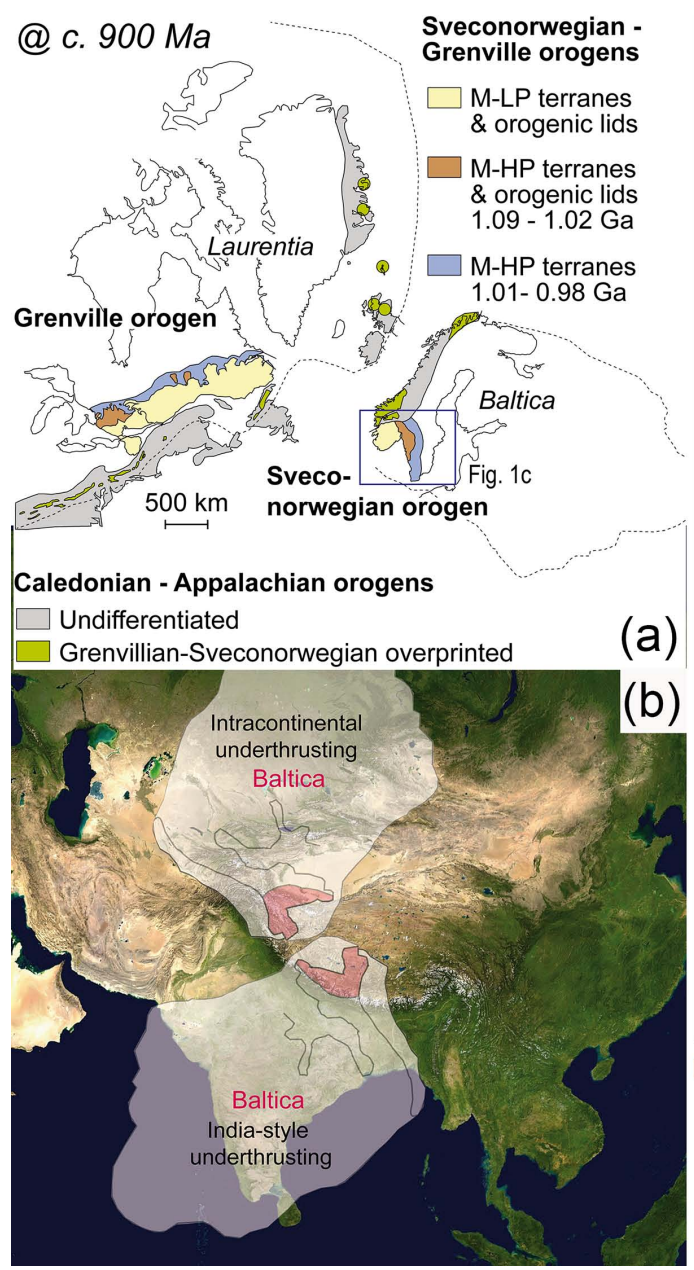

(c)

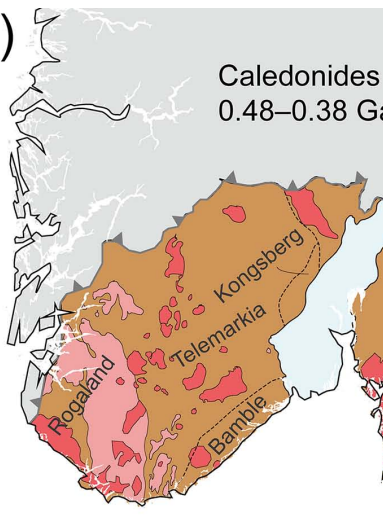

Sveconorwegian province 1.14-0.92 Ga

Eastern Segment

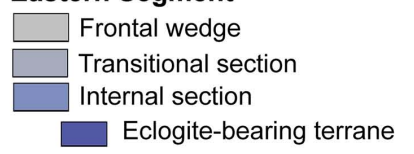

Western Sveconorwegian terranes

$\square$ Undifferentiated $<1.65 \mathrm{Ga}$ rocks

1.05-1.02 Ga granite

0.98-0.92 Ga Fe K gabbro-granite

SF - Sveconorwegian Front MZ - Mylonite Zone

Idefjorden Terrane
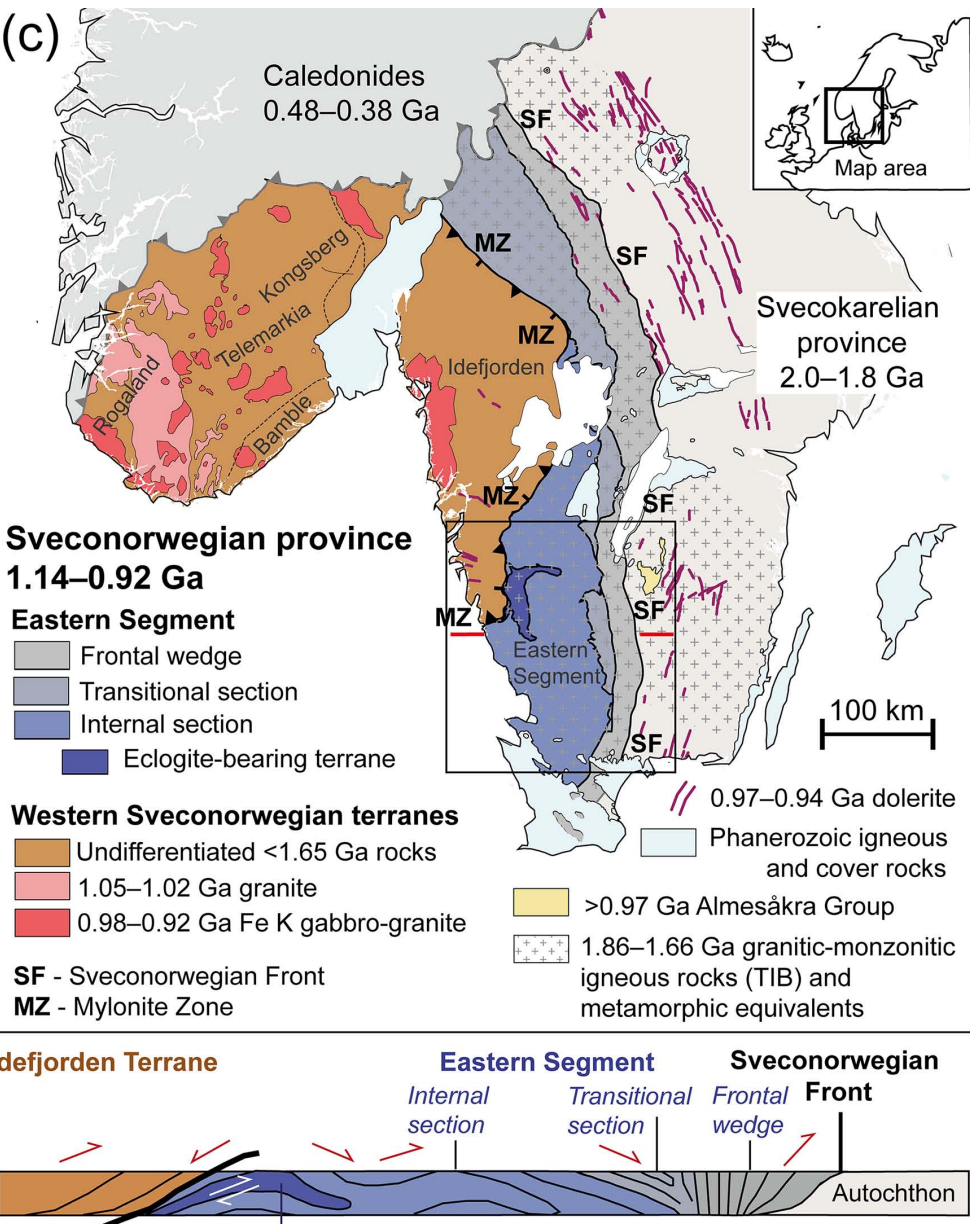

Mylonite Zone Eclogite-bearing terrane

This article is protected by copyright. All rights reserved. 


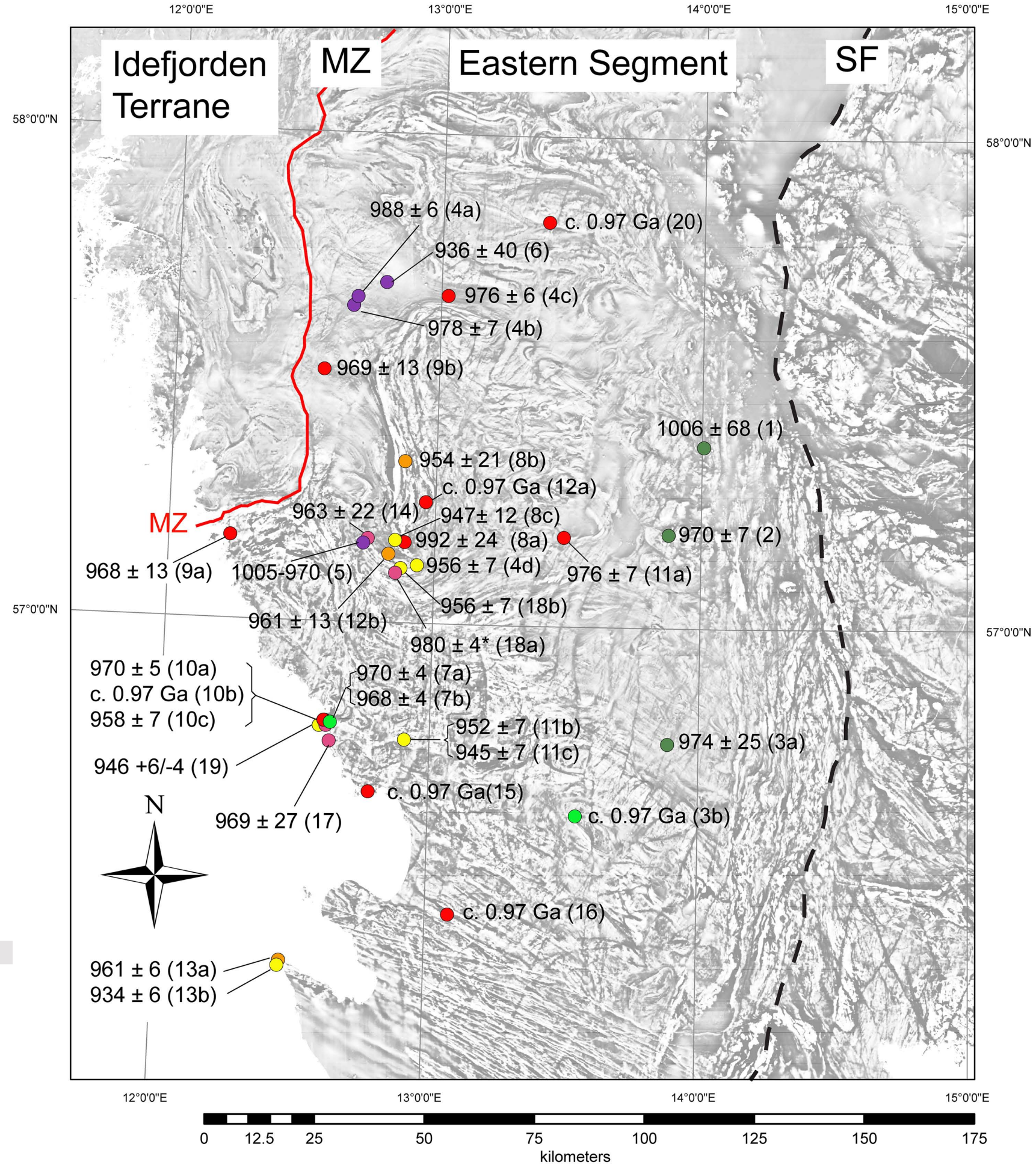

Metamorphic recrystallization of gabbro: 1.00-0.97 Ga

- Garnet amphibolite Eclogite

Crystallization of in situ partial melt: $0.98-0.97 \mathrm{Ga}$ - Migmatitic garnet amphibolite

- Migmatitic granitic gneiss

Crystallization of syn-kinematic melt: $0.96 \mathbf{G a}$

- Syn-kinematic pegmatitic/granitic dyke/vein
Metamorphic zircon (unclassified) in felsic rocks: $0.96 \mathrm{Ga}$

- Migmatitic orthogneiss, deformed pegmatite and granite dykes

Crystallization of post-kinematic melt:

0.96-0.93 Ga

$\bigcirc$ Undeformed post-kinematic pegmatitic/ granitic dyke/vein

This article is protected by copyright. All rights reserved. 


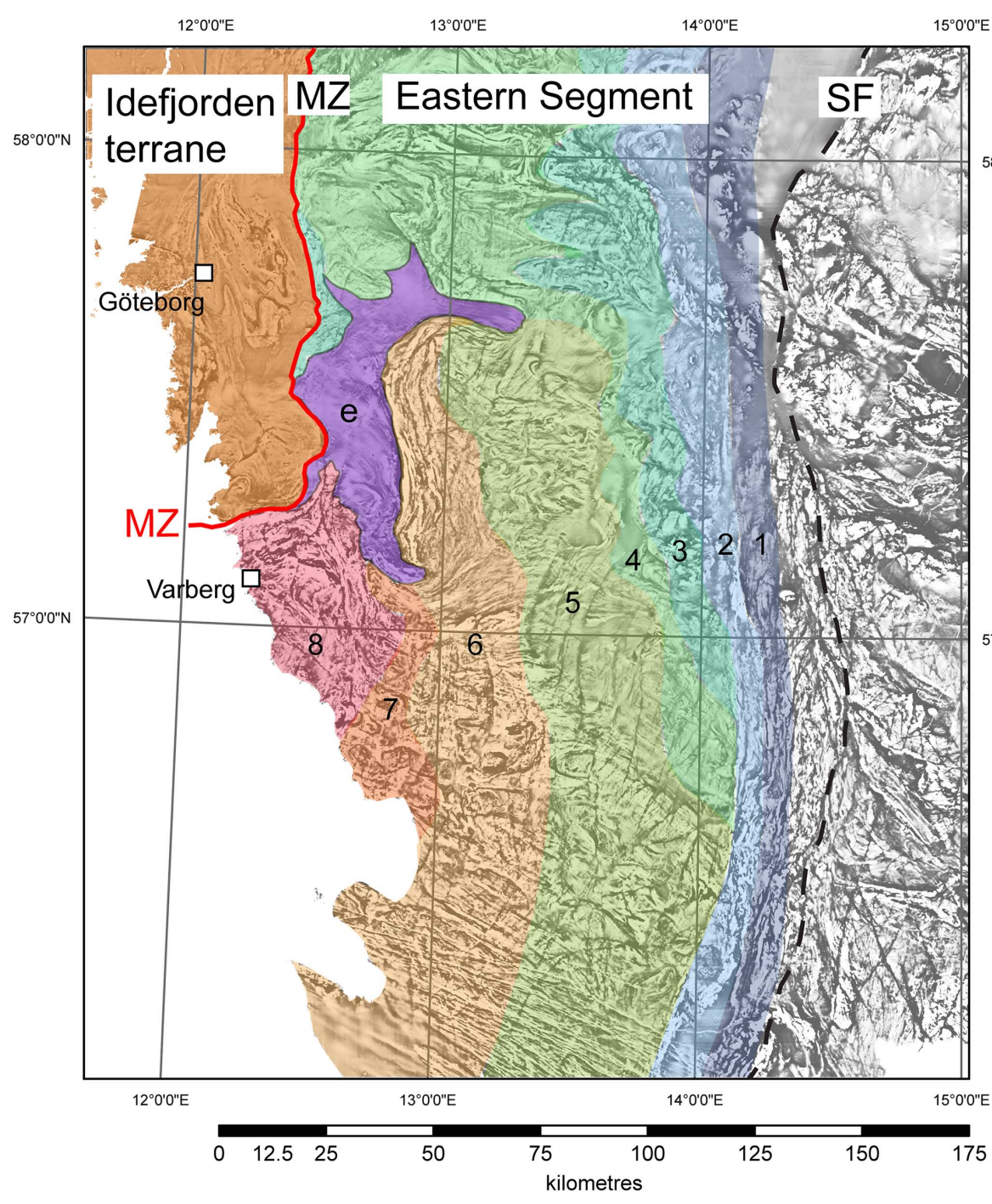

\section{LEGEND}

Idefjorden Terrane

U Undifferentiated

${ }^{58^{\circ} \mathrm{O}^{\circ} \mathrm{N} N}$ 'Mylonite Zone'

MZ lithotectonic boundary

Eastern Segment

metamorphic zones

\begin{tabular}{c|l}
\hline $\mathrm{e}$ & $\begin{array}{l}\text { Eclogite-bearing } \\
\text { terrane }\end{array}$ \\
\hline Thrust
\end{tabular}

8 Mega-Grt in leucosome $+\mathrm{Grt}+\mathrm{Cpx}+$ olive-green $\mathrm{Hb}$ $\pm \mathrm{Opx}+\mathrm{Bt}+\mathrm{PI}+\mathrm{llm}$

7 Opx-mbst in leucosome $+\mathrm{Grt}+\mathrm{Cpx}+$ olive-green $\mathrm{Hbl}$ $\pm \mathrm{Opx}+\mathrm{Bt}+\mathrm{Pl}+\| \mathrm{Im}$

$6 \quad \mathrm{Grt}+\mathrm{Opx}+\mathrm{Cpx}+\mathrm{PI}$ $57^{\circ} 0^{\circ} 0^{\prime} \mathrm{N}$ olive-green $\mathrm{Hbl}+\mathrm{Bt}+\| \mathrm{lm} \pm$ Antiperth

$5 \quad \mathrm{Grt}+\mathrm{Cpx}+\mathrm{PI}$ + olive-green $\mathrm{Hbl}+\mathrm{Bt}+\mathrm{llm} \pm \mathrm{Rt}$

4 Grt + olive $\mathrm{Hbl}+\mathrm{Pl}$ Appearance of leucosome

$3 \quad \begin{gathered}\text { Grt }+ \text { green } \mathrm{Hbl}+\mathrm{Pl} \\ +\mathrm{Bt}+\mathrm{llm}_{ \pm \mathrm{Ep} \pm \mathrm{Ttn}}\end{gathered}$

2 Grt + blue-green $\mathrm{Hbl}+\mathrm{Pl}$ $+B t+\| l m \pm E p \pm T t n$

1 Blue-green $\mathrm{Hbl}+\mathrm{Pl}$ $+\mathrm{Bt}+\mathrm{llm} \pm \mathrm{Ep} \pm \mathrm{Ttn}$

- - 'Sveconorwegian Front'

SF Eastern limit of

Sveconorwegian ductile deformation zones

This article is protected by copyright. All rights reserved. 

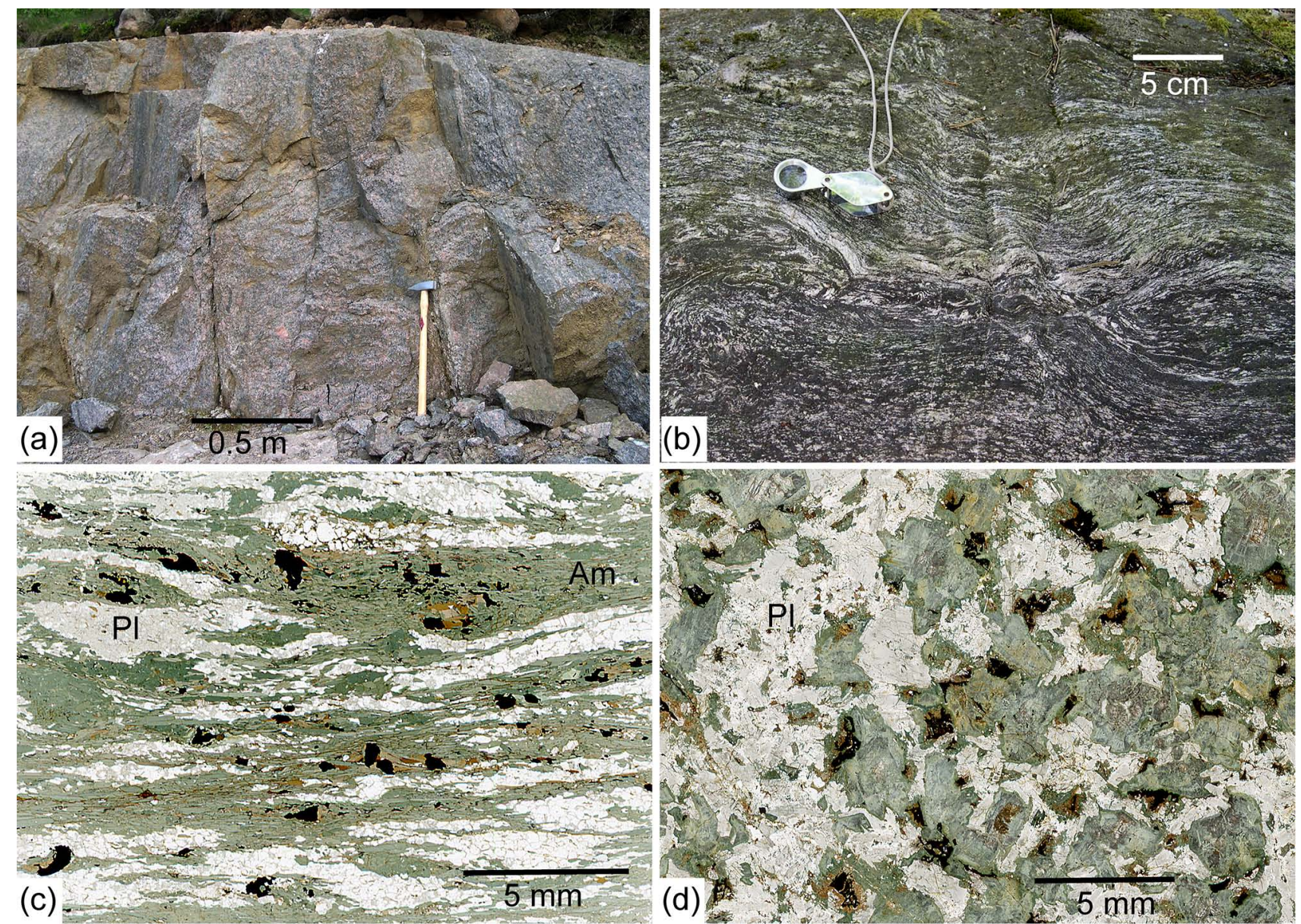

This article is protected by copyright. All rights reserved. 

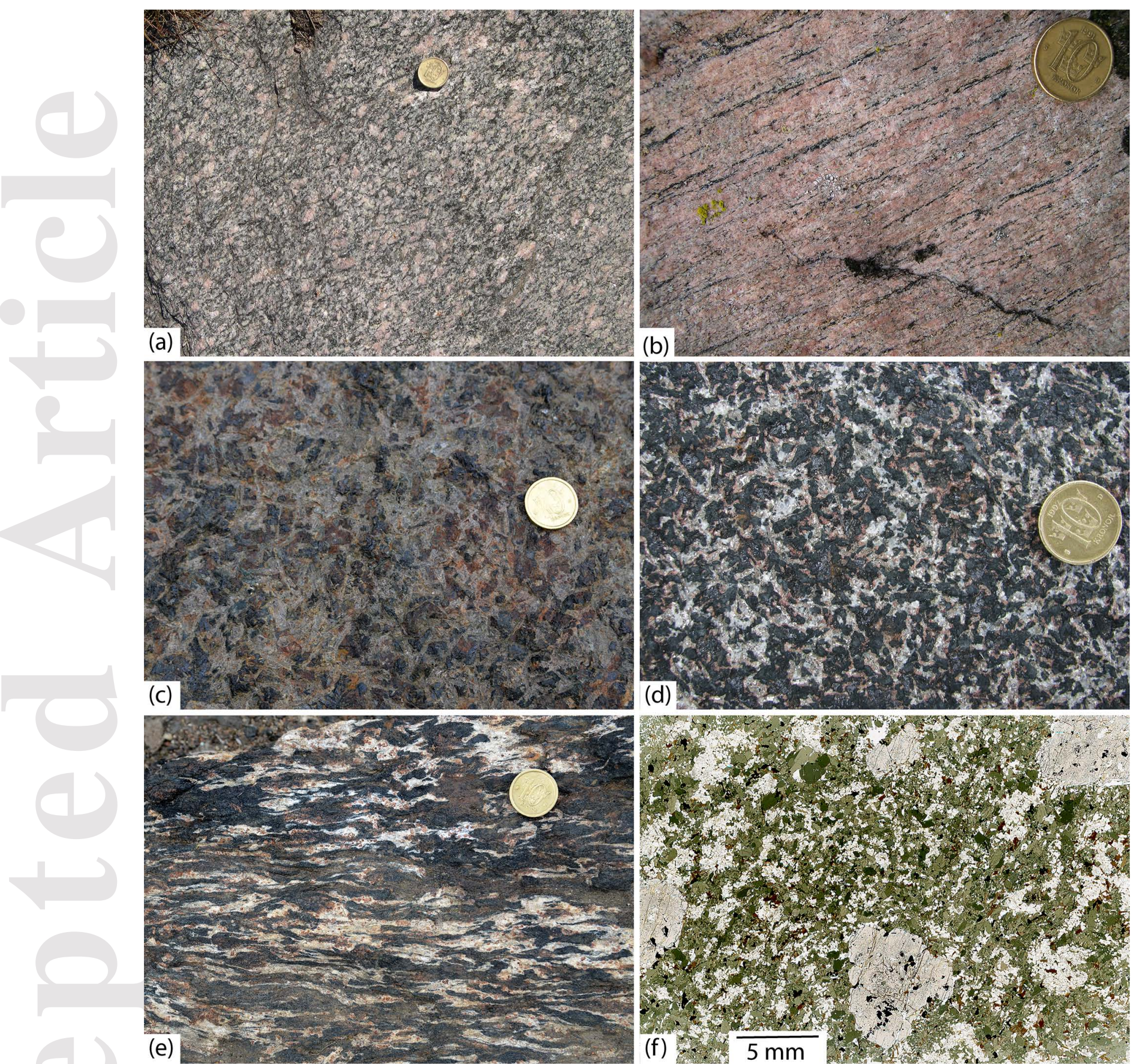

This article is protected by copyright. All rights reserved. 

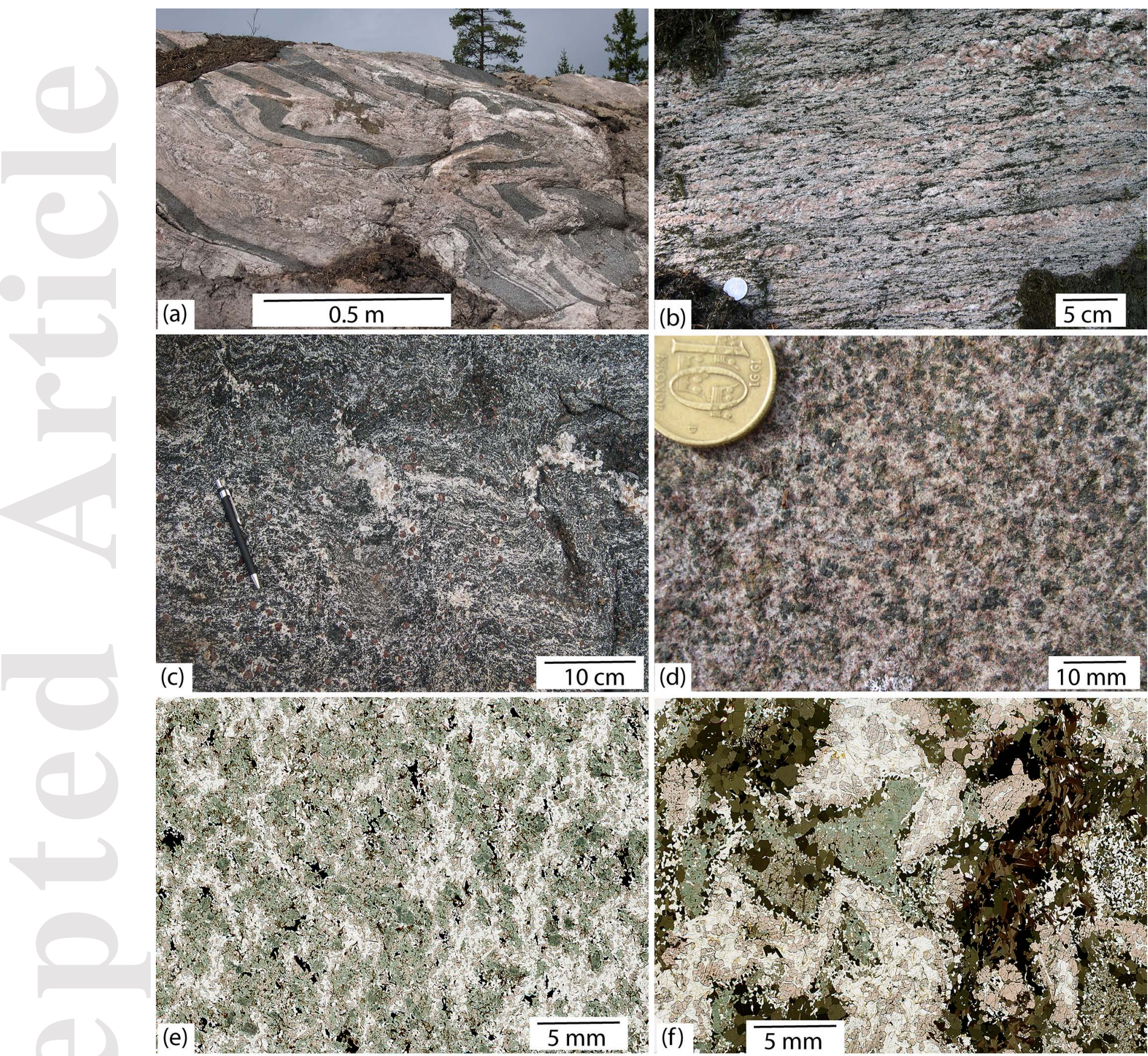

This article is protected by copyright. All rights reserved. 

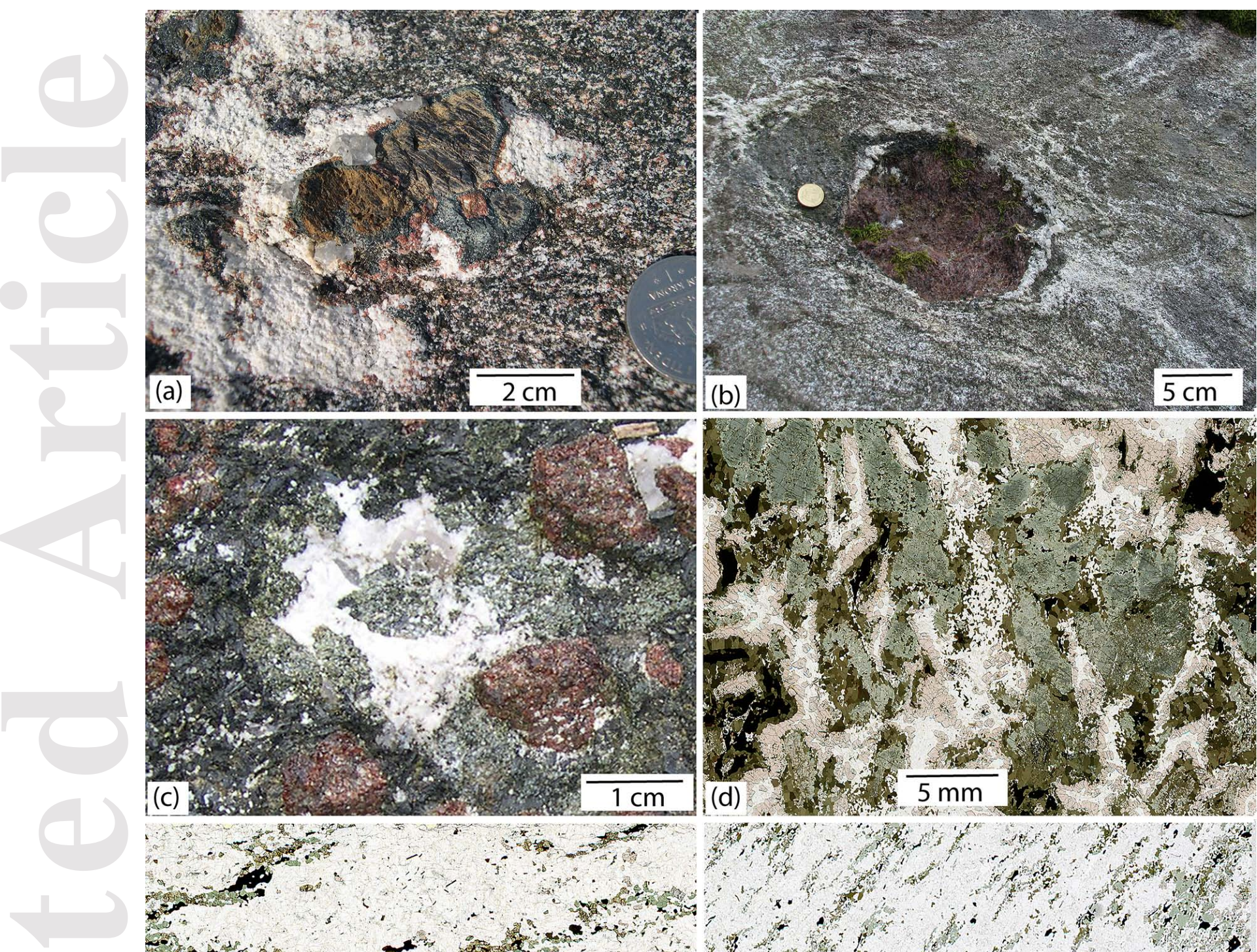

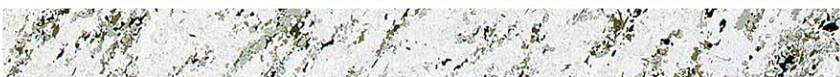

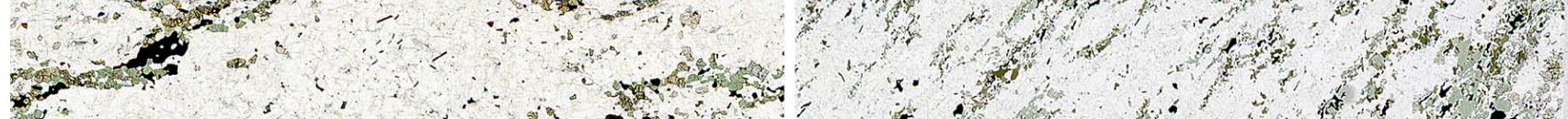

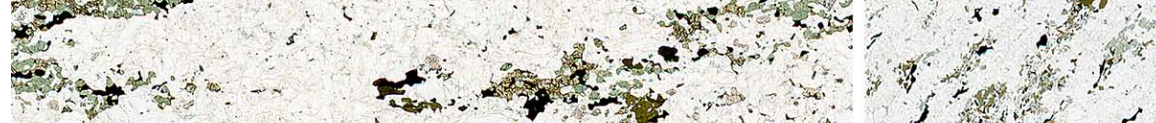

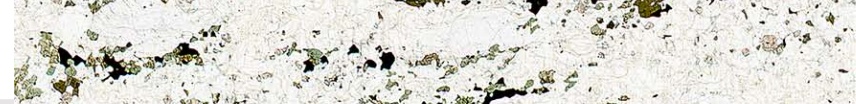

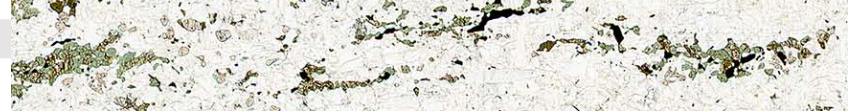
Wy

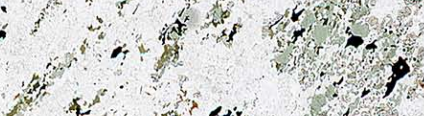
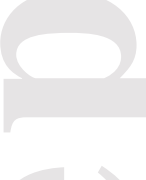

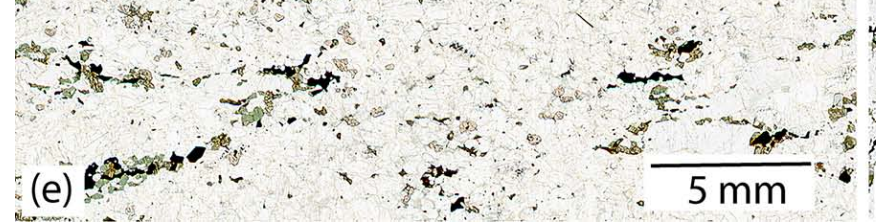
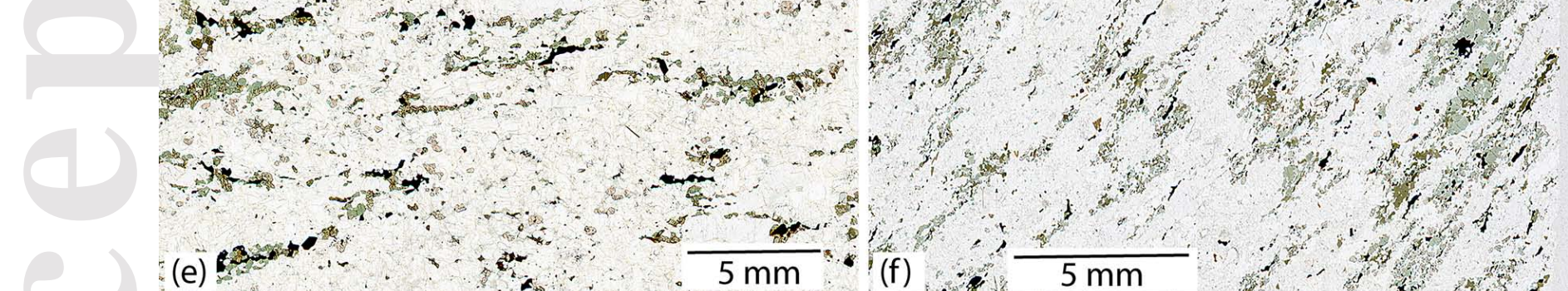

This article is protected by copyright. All rights reserved. 


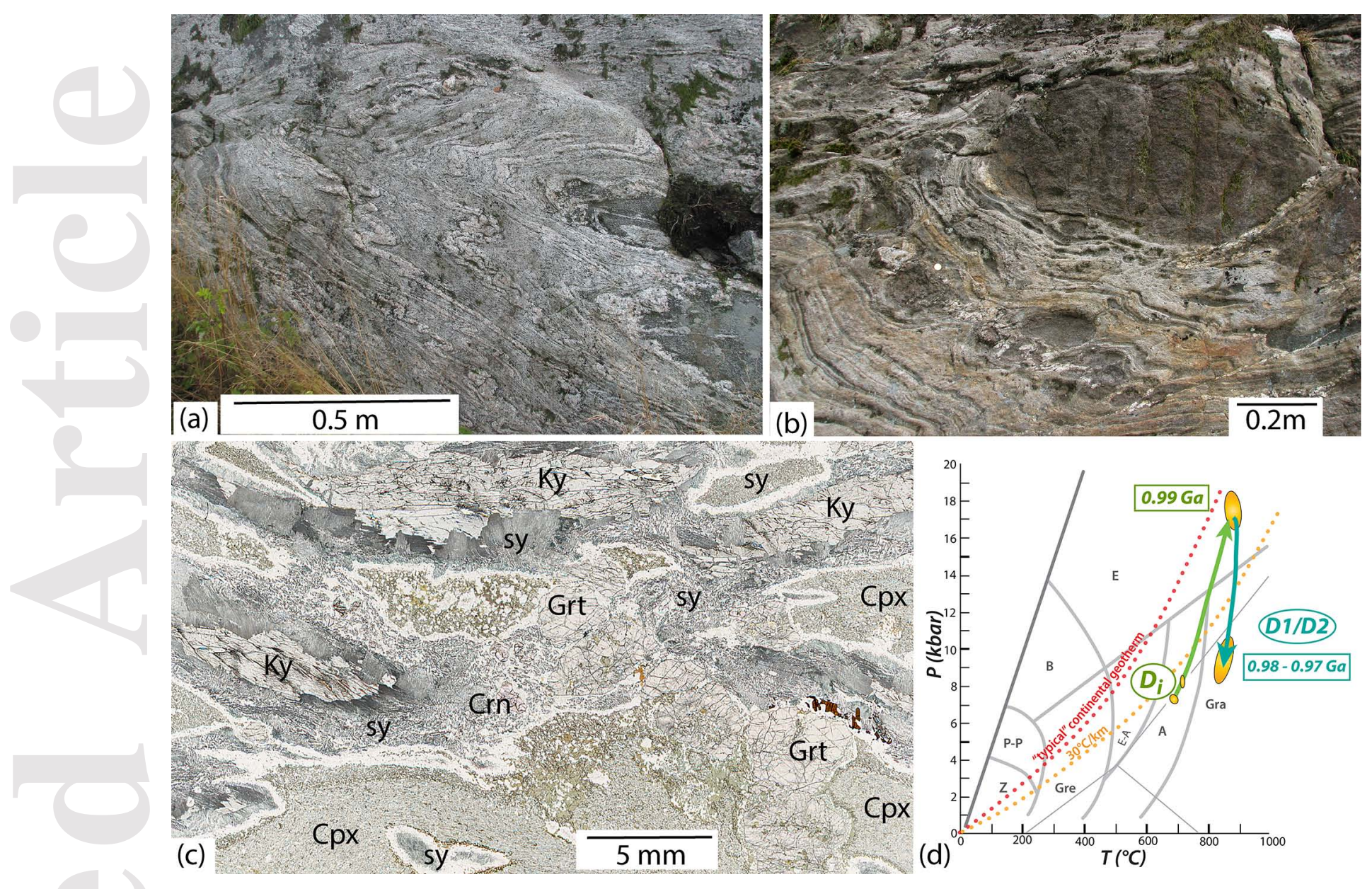

This article is protected by copyright. All rights reserved. 
$12^{\circ} 0^{\prime} \mathrm{O}^{\prime \prime} \mathrm{E}$

$13^{\circ} 0^{\prime} 0^{\prime \prime} \mathrm{E}$

$14^{\circ} 0^{\prime} 0^{\prime \prime} \mathrm{E}$

$15^{\circ} \mathrm{O}^{\prime} \mathrm{O}^{\mathrm{N}} \mathrm{E}$

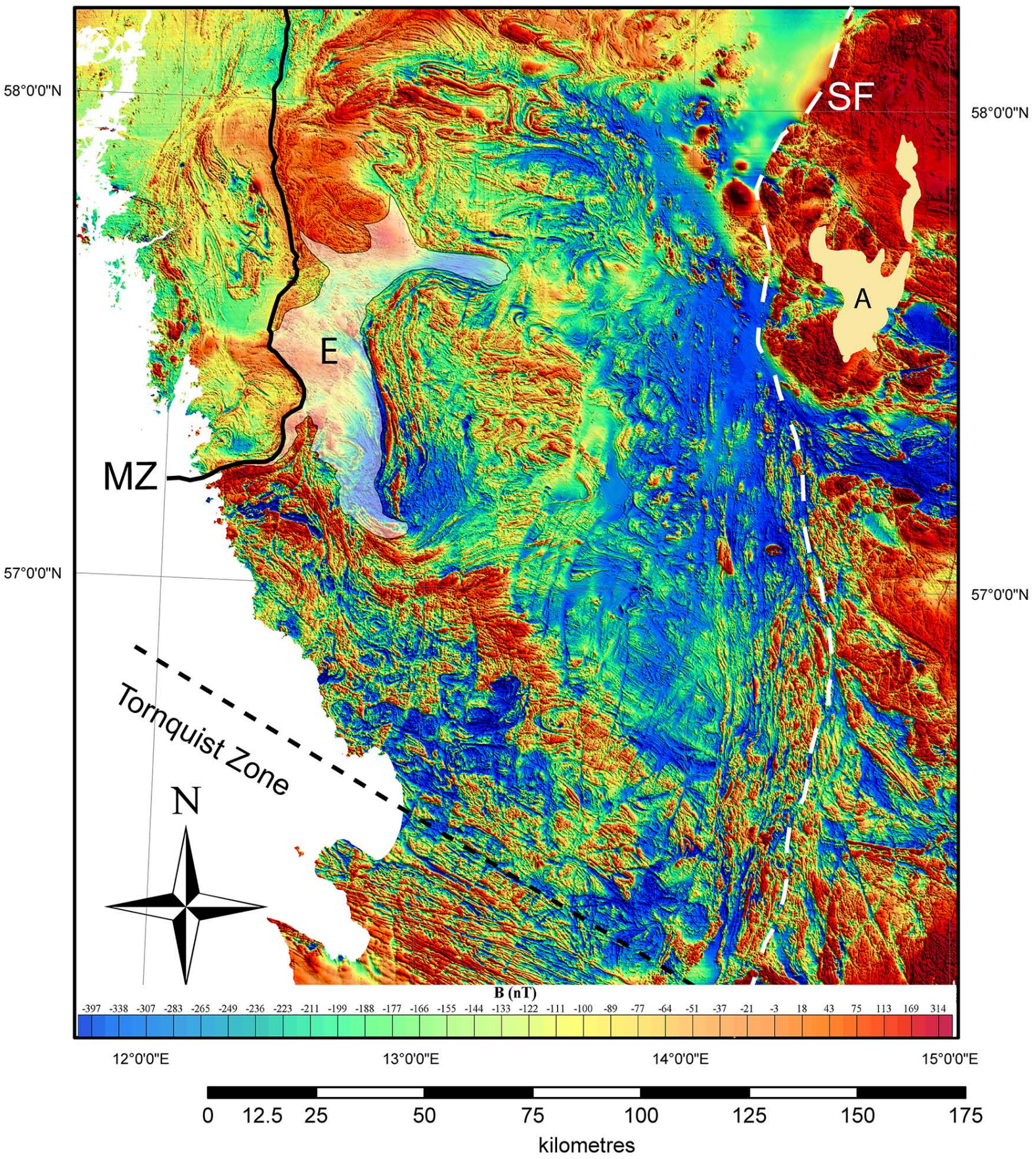

This article is protected by copyright. All rights reserved. 
(a) Himalaya-Tibetan orogen at present

N

(view from west)

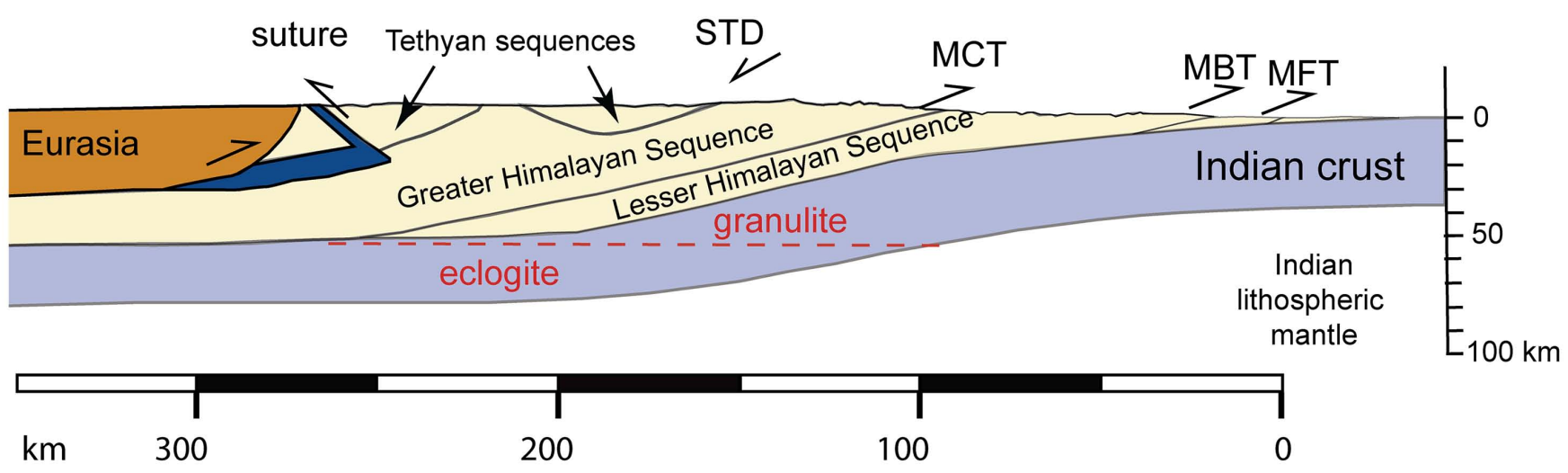

(b)

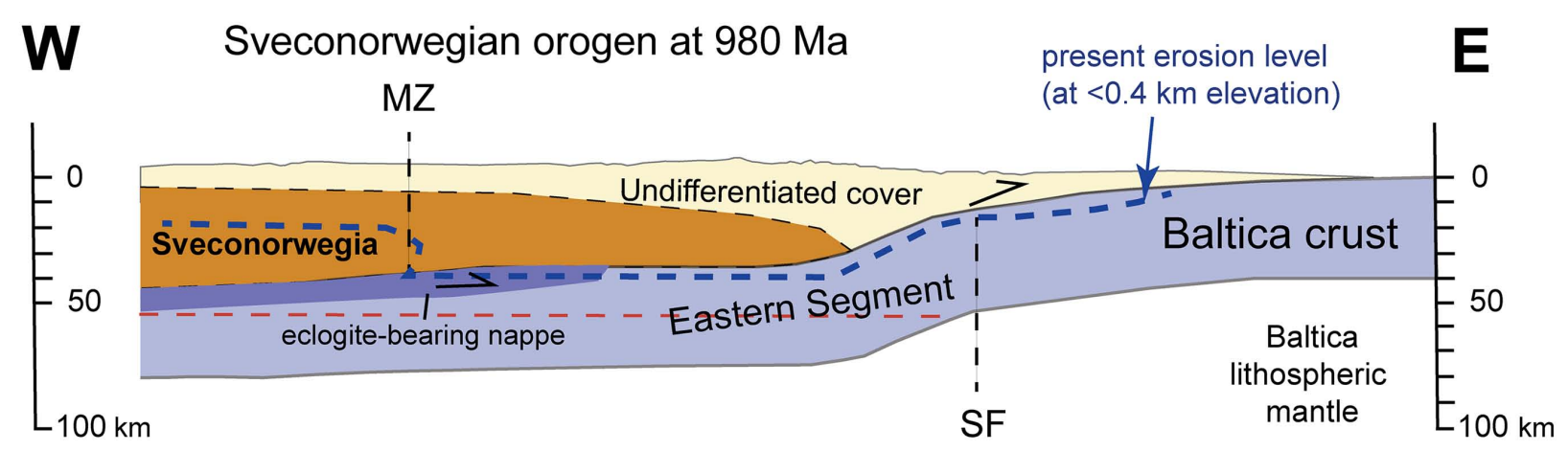

This article is protected by copyright. All rights reserved. 